\title{
Neutrophil Adaptations upon Recruitment to the Lung: New Concepts and Implications for Homeostasis and Disease
}

\author{
Vincent D. Giacalone ${ }^{1,2}\left(\mathbb{D}\right.$, Camilla Margaroli ${ }^{1,2}{ }^{-}$, Marcus A. Mall ${ }^{3,4}(\mathbb{D}$ and \\ Rabindra Tirouvanziam $1,2, * \mathbb{D}$ \\ 1 Department of Pediatrics, Emory University School of Medicine, Atlanta, 30322 GA, USA; \\ vincent.giacalone@emory.edu (V.D.G.); camilla.margaroli@gmail.com (C.M.) \\ 2 Center for CF \& Airways Disease Research, Children's Healthcare of Atlanta, Atlanta, 30322 GA, USA \\ 3 Department of Pediatric Pulmonology, Immunology and Critical Care Medicine and Cystic Fibrosis Center, \\ Charité-Universitätsmedizin Berlin, 13353 Berlin, Germany; marcus.mall@charite.de \\ 4 Berlin Institute of Health (BIH), 10178 Berlin, Germany \\ * Correspondence: tirouvanziam@emory.edu
}

Received: 29 December 2019; Accepted: 27 January 2020; Published: 28 January 2020

\begin{abstract}
Neutrophils have a prominent role in all human immune responses against any type of pathogen or stimulus. The lungs are a major neutrophil reservoir and neutrophilic inflammation is a primary response to both infectious and non-infectious challenges. While neutrophils are well known for their essential role in clearance of bacteria, they are also equipped with specific mechanisms to counter viruses and fungi. When these defense mechanisms become aberrantly activated in the absence of infection, this commonly results in debilitating chronic lung inflammation. Clearance of bacteria by phagocytosis is the hallmark role of neutrophils and has been studied extensively. New studies on neutrophil biology have revealed that this leukocyte subset is highly adaptable and fulfills diverse roles. Of special interest is how these adaptations can impact the outcome of an immune response in the lungs due to their potent capacity for clearing infection and causing damage to host tissue. The adaptability of neutrophils and their propensity to influence the outcome of immune responses implicates them as a much-needed target of future immunomodulatory therapies. This review highlights the recent advances elucidating the mechanisms of neutrophilic inflammation, with a focus on the lung environment due to the immense and growing public health burden of chronic lung diseases such as cystic fibrosis (CF) and chronic obstructive pulmonary disease (COPD), and acute lung inflammatory diseases such as transfusion-related acute lung injury (TRALI).
\end{abstract}

Keywords: margination; metabolism; scavenging; stress response; transcription

\section{Introduction}

Neutrophils comprise the largest proportion of circulating leukocytes in the human body and maintain a major presence in organs such as the lung. Consequently, despite being considered as terminally differentiated and endowed with a short lifespan after leaving the bone marrow, they are a major player in innate immunity. Their hallmark function is clearance of debris and pathogens through phagocytosis but they exhibit a diverse array of other immune functions. In addition to the direct phagocytosis of bacteria [1] and fungi [2], they limit the spread of microbes by releasing neutrophil extracellular traps (NETs) made of DNA through a process known as NETosis [3]. Although neutrophils are professional killers, they also have significant capacity to modulate the function of other immune cells. For example, through secretion of arginase-1 (Arg1) they suppress T-cell proliferation in the airways of cystic fibrosis (CF) patients [4] and limit T-cell function in the tumor microenvironment [5]. 
Similarly, the release of neutrophil elastase (NE) has been attributed to the alteration of macrophage function by the cleavage of Toll-like receptors (TLRs) and cytokines [6], T-cell function through the cleavage of surface co-receptors [7], and the modulation of secreted antibodies [8]. Diverse effector functions of secreted proteins, some of which are summarized in Table 1, are key for neutrophil adaptability and their far-reaching effects on immune responses.

Not only do neutrophils exhibit greater functional diversity than once thought [9], but they demonstrate the ability to reprogram and adapt to local microenvironments upon recruitment to tissues. This is in contrast with the conventional view holding these cells as terminally differentiated once released from the bone marrow. For example, a recent report details neutrophil reprogramming in a model of atherosclerosis via oxidized calmodulin-dependent protein kinase II driving a pro-inflammatory phenotype alongside the suppression of homeostatic transcription factors [10]. Neutrophil adaptation in the context of CF lung disease has been reviewed extensively $[11,12]$ and has incited further investigation into neutrophil reprogramming in other diseases. Of particular interest is neutrophil adaption upon recruitment to the lung, due to the role this organ plays as a major neutrophil reservoir [13,14]. There is a rapidly increasing prevalence of chronic inflammatory lung diseases such as asthma and chronic obstructive pulmonary disease (COPD) in the global population, in part due to increased exposure to air pollution [15]. In addition, aging populations are faced with increased risk for common nosocomial infections such as bacterial pneumonia, which results in sustained neutrophil recruitment to the lung but reduced efficacy in clearing infections [16]. Neutrophilic inflammation is also a key component of progressive lung damage in patients with CF $[17,18]$, which is one of the most common fatal hereditary diseases [19]. A greater understanding of pathological features of neutrophils in such lung pathologies is critical to improving treatment options for both acute and chronic inflammatory diseases.

Table 1. Diverse roles of neutrophil signaling and effector proteins. Neutrophil effector proteins, such as proteases and phagocytic receptors, and receptors involved in chemotaxis, contribute to the plasticity of neutrophils in driving inflammation, promoting resolution, or maintaining homeostasis. Abbreviations: Arg1, arginase-1; iNOS, inducible nitric oxide synthase; LAIR-1, leukocyte-associated Ig-like receptor 1; MPO, myeloperoxidase; MMP-9, matrix metalloproteinase-9; NOX, nicotinamide adenine dinucleotide phosphate oxidase; NE, neutrophil elastase; oxCAMKII, oxidized calmodulin-dependent protein kinase II.

\begin{tabular}{ccc}
\hline Protein & Role & Function \\
\hline Arg1 & pro/anti-inflammatory & suppresses T-cell proliferation [4] \\
BCL6 & pro/anti-inflammatory & suppresses neutrophil apoptosis [20] \\
CD200R & anti-inflammatory & attenuates oxidant production by neutrophils [21] \\
CXCR2 & pro-inflammatory & promotes chemotaxis as receptor for CXCL1 [22] \\
CXCR4 & homeostatic & promotes retention in bone marrow/lung as receptor to CXCL12, [23] \\
Dectin-1 & pro-inflammatory & promotes phagocytosis of fungi [24] \\
iNOS & pro-inflammatory & supports the generation of nitric oxide [25] \\
LAIR-1 & anti-inflammatory & suppresses neutrophil recruitment [26,27] \\
MPO & pro-inflammatory & supports generation of hypochlorous acid [28] \\
MMP-9 & pro-inflammatory & degrades the extracellular matrix [29] \\
NOX & pro-inflammatory & supports the generation of superoxide [1] \\
NE & pro-inflammatory & degrades phagocytosed microbes [1] and extracellular matrix [30] \\
oxCAMKII & pro-inflammatory & activates STAT1 and generation of inflammatory mediators [10] \\
\hline
\end{tabular}

\section{Homeostasis}

Like every tissue in the body, the lung is characterized by a specific immune profile. Circulating neutrophils are retained in the lung microvasculature, forming a reservoir defined as the lung-marginated neutrophil pool. The first observation of leukocyte sequestration in the lung microvasculature was reported in 1910 by F.W. Andrewes during a series of lectures held for the Royal College of Physicians in London [31]. Subsequently, the use of radiolabeling and adoptive 
transfer techniques allowed the identification of a marginated neutrophil pool in the capillary bed of the lungs, which was found to be in a dynamic equilibrium with the circulating pool [13,32-35]. The causes for neutrophil margination in the lung capillary bed had been initially attributed to several factors, including the size of the capillary vessel, the time required for a neutrophil to adapt its shape, hemodynamics, and to physical interactions with the lung endothelium [36-40]. However, differences in blood flow in the pulmonary arterioles and venules and the waterfall effect support a major role for physical interactions with the endothelial layer rather than a merely hemodynamic cause [41,42]. Indeed, the potential roles of selectins and integrins in orchestrating neutrophil margination in the lung capillary bed have been investigated. However, one should consider that the endothelium is a highly dynamic tissue programmed to respond quickly to internal and external cues. Therefore, its surface protein landscape changes upon different stimuli. At steady state, CD11/CD18 or L-selectins may not play a central role in the retention of neutrophils into the lung capillary bed $[43,44]$. However, other selectins cannot be excluded since treatment with fucoidin, an inhibitor of selectin-mediated adhesion, has been shown to partially disrupt neutrophil margination in the lung microvasculature [45]. Recent advances in intravital microscopy and genetically engineered mouse models have improved our understanding of neutrophil biology related to their margination to the capillary bed. Interestingly, a study by Devi et al. implicated the CXCR4/CXCL12 axis in neutrophil margination in the lung [23], pointing at CXCR4 as a retention marker (rather than a marker for aging neutrophils, as it is sometimes viewed).

Since the first observation of leukocyte retention made by Andrewes in 1910 [31], a physiological role for neutrophil margination to the lung has been sought. Several groups have hypothesized that neutrophil margination acts as a protective mechanism to de-prime and sequester activated neutrophils, thus preventing further damage [46-48]. Recently, supported by the observation that marginated lung neutrophils express the major histocompatibility complex II and interact with B cells in the lung microvasculature [49], Granton et al. hypothesized that the lung-as with the spleen and liver-may act as an immunological niche [50]. While both theories may support physiological roles to maintain homeostasis and control the immune response, more studies will be needed to elucidate the role for neutrophil margination in the lung microvasculature at steady-state and upon stress responses (Figure 1). The large surface area of the lung environment is indeed constantly exposed to inhaled pathogens and other environmental stimuli, and having abundant neutrophils in the immediate vicinity allows for an efficient and rapid innate immune response. 


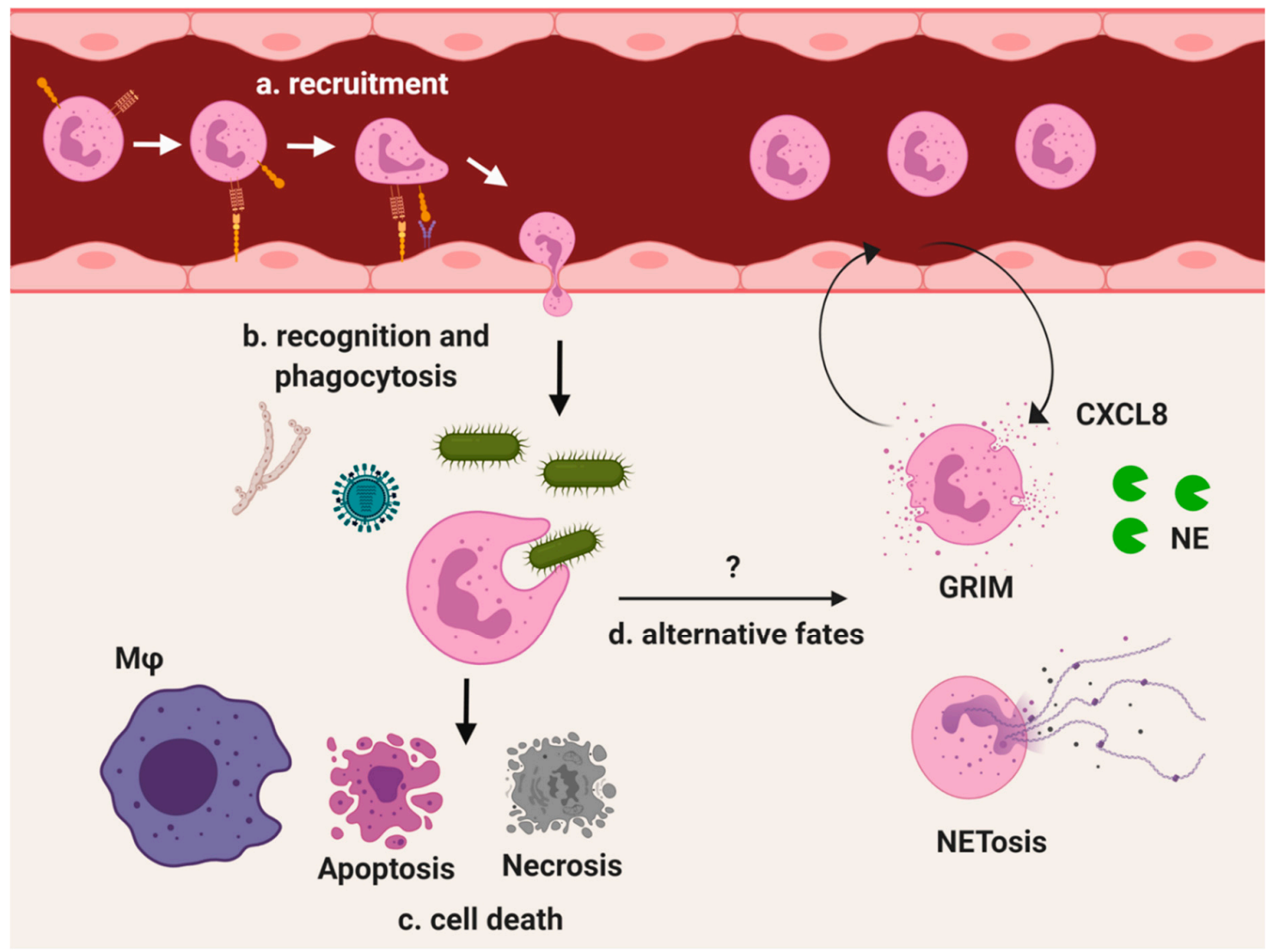

Figure 1. Overview of neutrophil recruitment and response in the lung. As a major neutrophil reservoir, the lungs are an important environment in the study of neutrophil biology, both at homeostasis and in responding to inflammatory stimuli. (a) Endothelial cells upregulate P-selectin to bind P-selectin glycoprotein ligand-1 on circulating naive neutrophils. Upon slowing down, neutrophil $\beta 2$ integrin binds with higher affinity to ICAM-1 on the endothelial cell surface followed by extravasation into the tissue. (b) Recruited neutrophils recognize pathogen-associated molecular patterns from all types of pathogens by surface pattern recognition receptors. Phagocytosed pathogens are degraded internally by fusion of the granules with the phagosome. (c) Neutrophils quickly apoptose and are cleared by tissue macrophages. (d) Neutrophil recruitment can also lead to alternate fates. Dysregulated neutrophil responses in diseases such as CF and COPD include the GRIM (granule releasing, immunomodulatory, and metabolically active) phenotype which exhibits active degranulation but impaired pathogen clearance. The release of NE damages host tissue while sustained CXCL8 production drives further neutrophil recruitment. Neutrophils can also expel their DNA through NETosis, but may survive and retain phagocytic capability.

\section{Stress Response}

Unlike some of the longer-lived leukocytes featured in both arms of the immune system, such as mast cells in the innate system and memory T cells and long-lived plasma cells in the adaptive system, neutrophils do not maintain long-term tissue residence. However, they are invaluable for their ability to respond rapidly and in massive manner to almost any type of stress inflicted upon peripheral tissues. The hallmark function of neutrophils is microbial clearance, especially of bacteria, by phagocytosis. It is now well understood how bacteria are captured and digested internally [1,51], but neutrophils are also well equipped to clear viruses [52,53] and fungi [2], as well as contribute to defense against parasites [54]. 


\subsection{Bacterial Infections}

Responding to bacterial infections is the most well-characterized function of neutrophils. With the increased focus on innate immunity in recent years, we are now learning more about the complexity of pathogen identification and clearance in specialized areas such as the lung. Although neutrophils are characterized by pre-programmed functions, their ability to carry out these functions is highly dependent on the specific conditions of their microenvironment. For example, a recent report by Lei et al. details the differences in neutrophil response to Group A Streptococcus in the lungs compared to the skin. While this bacterial species is efficiently cleared from the lungs of mice by a nicotinamide adenine dinucleotide phosphate oxidase (NOX)-dependent mechanism, clearance is impaired in the skin [55]. This discrepancy may be due to creation of an anoxic environment in the skin, which favors the growth of this organism but hampers oxidative burst by neutrophils. Indeed, NOX-dependent generation of reactive oxygen species (ROS) is a crucial component of a neutrophilic response [1]. The CD200 receptor has been shown to play a role in driving lung pathology during influenza infection, as blocking this receptor attenuated macrophage-associated inflammation [56]. However, blocking this receptor on neutrophils during pulmonary Francisella tularensis infection in mice augmented infection by reducing ROS production [21]. Although there are scenarios in which it would be beneficial to counteract excessive ROS production, for bacterial and fungal infections [57] as well as viral infections [58], this finding demonstrates the potential benefit of boosting ROS production in certain cases. For example, boosting innate immune responses following influenza infection in mice by overexpression of granulocyte-macrophage colony-stimulating factor in the lungs was found to protect against Staphylococcus aureus-induced pneumonia by enhancing ROS production in alveolar macrophages but not neutrophils. Neutrophils were, however, essential for protection and the mice did not experience excessive inflammation resulting from elevated ROS production [59]. In another example, ROS production was enhanced by treatment with an angiotensin-converting enzyme inhibitor, which promoted the killing of methicillin-resistant $S$. aureus [60]. This mechanism may not only apply to enhancing the antimicrobial response. For example, it has also been implicated in the stimulation of wound healing through enhancing the differentiation of pro-resolution macrophages in the liver [61].

Of equal importance to ROS in the destruction of bacteria are reactive nitrogen species such as nitric oxide (NO) [62] which are produced by neutrophils to a high degree in diseased airways [63]. Inducible nitric oxide synthase (iNOS) is the enzyme complex responsible for generating NO using arginine as a substrate [25] and has long been known to be highly activated in neutrophils in response to bacterial infection [64]. However, neutrophils are not the sole source of NO produced in tissues, as it is also produced by endothelial cells [65] and macrophages. NO production by all cells can be inhibited by Arg1, which competes with iNOS for arginine as a substrate [66], and is actively secreted by neutrophils in chronic diseases such as CF [4] and cancer [67]. While RNS are important microbicidal mediators, they can have detrimental effects when released from activated neutrophils and other cells. In a study by Kumar et al. looking at septic patients with confirmed bacterial infections, neutrophils were found to have increased iNOS activity. Nitrite, a metabolite of NO, was measured in the plasma and found to inversely correlate with lung function [68]. While lung function was likely impacted by other aspects in this severe pathological condition, these findings emphasize the potency of a neutrophilic response in impacting the function of organs such as the lungs. In an in vitro model of sepsis, Shelton et al. found that neutrophil iNOS activity contributed to leakage across an endothelial barrier with evidence that peroxynitrite, produced by $\mathrm{NO}$ reacting with $\mathrm{O}_{2}{ }^{-}$, mediates this effect [69]. While this model did not directly use bacterial challenge, it employed mixtures of cytokines important for sepsis in humans, which is defined as "life-threatening organ dysfunction caused by a dysregulated host response to infection" [70], in which neutrophilic inflammation is an important component [71].

Another antimicrobial mechanism involves the release of histone-bound DNA complexed with primary granule proteins, such as NE and myeloperoxidase (MPO), in the form of NETs [72]. Formation of NETs is regulated by a complex pathway requiring histone citrullination by peptidyl arginine deiminase 4 (PAD4) followed by decondensation of the chromatin [73], which has more recently been 
shown to be promoted by histone acetylation using broadly acting inhibitors of histone deacetylase [74]. Mechanisms independent of PAD4 have also been described $[75,76]$. NETosis has been classically viewed as a cell death pathway but neutrophils have been shown to maintain viability and anti-bacterial functionality following NET release [77,78]. Although the exact role of NETosis in cellular fate is still under debate $[79,80]$, this process has demonstrated importance in the neutrophilic response to bacterial lung infections, including bacterial pneumonia. In a study of patients with ventilator-associated pneumonia, the presence of NETs was assessed by measuring complexes of DNA and MPO. NET presence was found to be elevated in acute respiratory distress syndrome (ARDS) patients with ventilator-associated pneumonia compared to ARDS alone, and correlated with both bacterial burden and CXCL8 [81]. Considering that MPO has been found to be elevated in the airways of ARDS patients [82] and that this enzyme is associated with lung damage in CF [83,84], NET-associated MPO may be a contributing factor in progression of disease in ARDS. Studies of NETosis are also contributing to a better understanding of neutrophil plasticity. Although typically thought of as having minimal transcriptional activity, NETosis has been shown to be dependent on transcription. Khan and Palaniyar demonstrated that inhibition of transcription using Actinomycin D attenuated NETosis in response to the bacterial stimulants lipopolysaccharide and ionomycin [85]. This finding implicates transcription as a potential target of inhibition for treating NET-related pathologies. Another therapeutic target related to NETs formation is Type I interferon. A recent finding suggests that Type I interferon-driven NETosis may promote respiratory P. aeruginosa infections in mice by providing a scaffold to support biofilm production [86]. Interruption of interferon signaling may, therefore, be useful for suppressing infection by biofilm-capable organisms, but care would need to be taken not to increase susceptibility to viral infection. Finally, when considering the cost-benefit of NETosis, with regards to its anti-microbial properties and its association with disease pathology, one should consider the balance between the number of neutrophils present at the site of inflammation vs. those undergoing NETosis. While this quantification may be challenging to measure, especially in vivo, it may clarify its impact on the fitness of the host in a specific inflammatory setting.

\subsection{Viral Infections}

Although neutrophils are most thoroughly studied in the context of antibacterial responses, a growing body of literature demonstrates their importance in responding to viral infection, as well. The adaptations they undergo in this role, especially when recruited to the airways, have major implications for disease outcome and eventual resolution of inflammation since neutrophil-driven innate immune mechanisms can mount a rapid antiviral response even in the absence of memory B- and T-cell responses $[87,88]$. The fine balance of neutrophilic inflammation in response to respiratory tract viral infections is exemplified by a variety of findings that may appear contradictory. For example, a recent study demonstrated that activation of the NOD-, LRR- and pyrin domain-containing protein 3 (NLRP3) inflammasome improves survival during influenza A virus (IAV) infection in mice by recruiting neutrophils via interleukin-1 $\beta$ [89]. However, neutrophils do not provide a universal protective effect during influenza infection. Studies using aged mice have demonstrated overall higher neutrophil presence in the lung during IAV infection, but impaired migration towards the chemoattractant CXCL1 and reduced expression of the corresponding receptor CXCR2 on bone marrow neutrophils. Depleting neutrophils after infection was also shown to promote survival without impairing clearance [22]. Since overall neutrophil recruitment was not shown to be impacted while migration towards specific chemoattractant gradients was dysregulated, this demonstrates the need for more targeted immunomodulatory therapies focused on neutrophilic responses. A new potential target described in a recent study using a murine model of IAV infection is BCL6. This transcriptional regulator was shown to suppress neutrophil apoptosis specifically in airway neutrophils near the site of infection, while cells in the bone marrow and in circulation were unaffected. Mice with a myeloid cell deficiency in BCL6 exhibited improved survival and reduced inflammation when infected with IAV [20]. Modulating neutrophilic inflammation may therefore provide clinical benefit when 
chronic lung disease results from influenza infection [90]. However, careful consideration will likely be needed to determine which patients would benefit from an enhanced neutrophil response during viral infections, and which would benefit more from suppressing neutrophil activity.

While neutrophil adaptations in response to influenza infection are some of the best-studied, important findings with other viruses are continuing to direct much-needed focus toward the innate immune response to viral infections (Figure 2). It was recently demonstrated in a mouse model of respiratory syncytial virus (RSV) infection that while signaling through myeloid differentiation primary response 88 (MyD88) and TIR-domain-containing adapter-inducing interferon- $\beta$ (TRIF) is essential for neutrophil recruitment to the lung, signaling through mitochondrial antiviral-signaling protein (MAVS) is required for neutrophil activation and the production of key mediators including matrix metalloproteinase 9 (MMP-9), MPO, and NE [91]. RSV infection is associated with severe neutrophilic inflammation, sometimes contributing to mortality [92]. Resolving neutrophilic inflammation is therefore as important as suppressing the infection, and a recent report suggests that leukocyte-associated Ig-like receptor 1 (LAIR-1) fills this role during RSV infection. This receptor is not expressed on circulating neutrophils, but may be upregulated upon migration into tissues and subsequent activation [26]. RSV-infected mice lacking functional LAIR-1 exhibited greater neutrophil influx into the airways but had no indication of enhanced viral clearance [27].

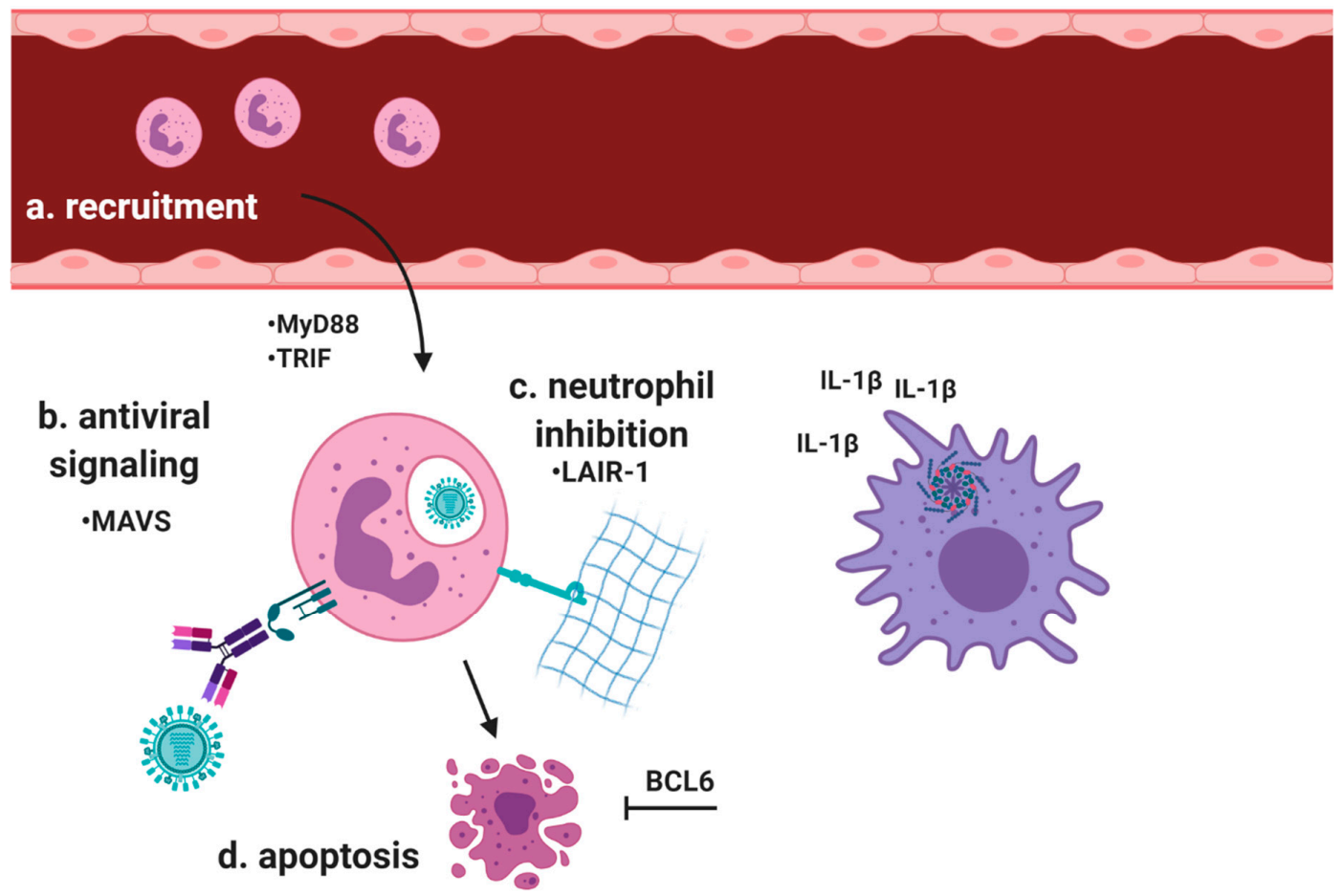

Figure 2. Neutrophil responses to viral infection. Neutrophils have an important role in antiviral immunity. (a) Neutrophils are recruited to sites of viral infection in the lung via signaling through MyD88 and TRIF. Interleukin-1 $\beta$ production by the NLRP3 inflammasome in resident antigen presenting cells drives recruitment. (b) once in the tissue, MAVS signaling initiates neutrophil activation and production of inflammatory mediators. Neutrophils engulf antibody-bound virions via surface Fc receptors. (c) The inhibitory receptor LAIR-1 binds collagen and suppresses neutrophil activity. (d) Transcriptional regulators such as BCL6 suppress apoptosis and represent a potential target for enhancing neutrophil-mediated antiviral immunity.

In addition to bacterial infection, NETosis has been described in the context of neutrophil responses to viral infection in previous reviews $[93,94]$. Studies of NETosis in response to respiratory viruses further establish the important implications of neutrophils in responding to viral infections, for both 
enhancing clearance and contributing to pathology. Murano et al. demonstrated that RSV is capable of inducing NETosis by the classical PAD4-mediated pathway. They also observed possible virion trapping demonstrated by co-localization of extracellular DNA lattices and primary granule proteins, including NE and MPO, with RSV F protein [95]. NETs have also demonstrated efficacy in the neutrophil response against HIV. Saitoh et al. demonstrated that the initiation of NETosis by signaling through TLR-7 and TLR-8 promotes trapping and inactivation of HIV through activity of the effector proteins MPO and $\alpha$-defensin [96]. However, viral-induced NETosis can also have a detrimental impact on the host. In a mouse model of influenza infection, neutrophils from the bronchoalveolar lavage fluid were highly NETotic when co-incubated with infected epithelial cells and contributed substantially to lung injury [97]. In addition, blood neutrophils from influenza-infected patients have demonstrated a high propensity for NETosis when stimulated ex vivo, and NETosis was found to increase vascular permeability using an in vitro model [98]. Moreover, extracellular host DNA released in accordance with rhinovirus infection has been observed to correlate with a shift towards a type 2 immune response in humans, typically associated with allergic disease. Using a murine model of rhinovirus infection, Toussaint et al. then demonstrated that infection promotes NET formation and inhibition of NETosis reduced type 2 immune pathology [99]. While sometimes effective in limiting viral infection, further research is needed to determine if the risks of anti-viral NETosis outweigh the potential reward as a therapeutic target.

\subsection{Fungal Infections}

In addition to bacteria and viruses, neutrophils can mount a powerful response to fungi as well. One of the major culprits behind respiratory fungal infections is Aspergillus fumigatus, which promotes potent neutrophilic inflammation [100] induced in part by the regulation of the Von Willebrand factor via cleavage by a disintegrin and metalloproteinase with a thrombospondin type 1 motif, member 13 [101]. In addition to their role in clearance of spores and hyphae [102], neutrophils play a key role in regulating the antifungal adaptive immune response. In neutropenic mice infected with $A$. fumigatus, dendritic cells were found to accumulate in the lungs, but had impaired homing to the mediastinal lymph nodes. Dendritic cells were also found to lack expression of surface costimulatory molecules, but this defect was rescued by coincubation with neutrophils following Aspergillus exposure [103]. Considering that neutrophils are essential for guarding the lungs against fungal pathogens it is surprising that $\mathrm{CF}$ patients, who experience widespread neutrophilic inflammation in the airways, are highly susceptible to respiratory fungal infections [104]. The cause may be neutrophils themselves. Neutrophils acquire a dysfunctional phenotype in the CF airways which hampers their ability to clear bacteria, despite attaining a high state of activation where they exocytose their primary granules [105]. Exocytosis of primary granules releases NE into the extracellular environment, and this protease has been found to cleave the pattern recognition receptors dectin-1 and 2 [24], which are important phagocytic receptors for fungal pathogen-associated molecular patterns such as $\beta$-glucan $[106,107]$. Cleavage of these receptors by NE inhibited the antifungal response in infected mice [24], and the airway fluid from CF patients has been found to have a high prevalence of extracellular NE [108]. Neutrophil elastase drives multiple aspects of CF lung disease, including increased mucus production and impairment of mucociliary clearance [109]. Both outcomes promote colonization of the airways by opportunistic fungal pathogens such as Aspergillus, which has a complex array of interactions with airway mucins [110]. Considering that this protease is being actively secreted by neutrophils undergoing pathological conditioning in the CF airways [105], with similar dysfunctions observed in other respiratory diseases [111], NE inhibition may offer a therapeutic option for treating pulmonary fungal infections. Indeed, pyrimidine derivatives in some NE inhibitors have antifungal properties [112].

\section{Neutrophils in Chronic Respiratory Pathologies}

We are now building a greater understanding of how neutrophil responses to infectious challenge, especially in the lung, are far more complex than simply locating and clearing microbes. Their 
responsiveness to non-infectious challenge, for example with allergen and smoke exposure, is also a potent factor in innate immune responses. The ability of neutrophils to quickly resolve these challenges or contribute to pathology has major implications for both organ-specific and systemic health.

In the absence of infection, neutrophilic inflammation can be initiated and result in severe inflammatory pathologies. When neutrophils are recruited to the lungs in the absence of infection, in genetic disorders such as CF [12], or in diseases linked to environmental conditions such as COPD [113], they can cause extensive damage through release of their destructive granule contents such as NE and MPO [12,113]. They also exhibit potent immunomodulatory capabilities whereby they can substantially alter the immune balance of various environments $[4,114]$. In addition to ongoing tissue damage and altered adaptive immune responses, chronic neutrophilic pathologies are also characterized by neutrophil dysfunction where these cells are not able to effectively conduct their normal duties of debris and microbe clearance. A better understanding of how neutrophilic pathologies are initiated and how they might be corrected is essential for treating patients with rare diseases like $\mathrm{CF}$ that currently have few anti-inflammatory treatment options, as well as widespread diseases like asthma and COPD which are becoming ever-larger public health burdens each year.

\subsection{Cystic Fibrosis (CF)}

$\mathrm{CF}$ is a severe monogenic multiorgan disease that affects multiple epithelial organs, with the majority of morbidity and mortality due to airway disease [115]. Neutrophils have a central role in the development and persistence of airway disease and their role in pathology has been studied extensively [11,12]. Importantly, they have been shown to develop a unique inflammatory phenotype after recruitment into the CF airway lumen, where they maintain viability and exocytose their primary granules but have reduced ability to phagocytose bacteria in a distinct fate now called GRIM (granule releasing, immunomodulatory, and metabolically active) neutrophils $[105,116,117]$. Exocytosis of the primary granules, which are usually sequestered in the cytoplasm, results in release of effectors including NE, Cathepsin G, MPO and Arg1, which has been found to correlate with disease progression in mice with CF-like lung disease and young children and older patients with CF [118-120]. This pro-inflammatory phenotype with reduced ability to clear pathogens poses an intriguing paradox and is becoming a focal point in addressing CF lung disease. This failure of a major defense mechanism in the lungs is likely a contributing factor to the high susceptibility of $\mathrm{CF}$ patients to common environmental bacteria [121]. Directly causing lung damage through protease and oxidase release further implicates neutrophil dysfunction in being a major problem in CF lung disease that warrants additional research [109]. Prior studies of metabolic reprogramming in CF airway neutrophils may offer some explanation to how this dysfunctional phenotype is acquired. CF airway neutrophils activate the mechanistic target of rapamycin (mTOR) pathway [122] and increase expression of the Glut1 glucose transporter [123], which is controlled by mTOR [124]. Activation of the mTOR pathway and expression of Glut1 promotes utilization of glucose in CF airways [125]. Another aspect of reprogramming in $\mathrm{CF}$ airway neutrophils is increased production of the regulatory protein resistin [126], which is closely tied to insulin resistance [127]. While resistance to insulin impairs the uptake of glucose by cells, anabolic reprogramming of neutrophils in the CF airways enables them to effectively take in and utilize glucose to fuel pro-survival pathways $[105,122]$. The downside of this adaptation is that resistin decreases the ability of neutrophils to kill bacteria by inhibiting ROS production and actin polymerization, as noted for CF-associated pathogens P. aeruginosa and $S$. aureus [128].

\subsection{Asthma}

Asthma is among the most common chronic diseases in children and adults, and typically viewed as a Th2-mediated allergic disease featuring profound eosinophilic inflammation [129]. However, there is a growing focus on neutrophilic inflammation in non-atopic asthma [130,131]. One of the contributing factors to neutrophilic asthma is respiratory infections. For example, Patel et al. demonstrated that 
young asthmatics who tested positive for Chlamydia pneumoniae exhibited elevated neutrophil counts and CXCL8, a powerful neutrophil chemoattractant, in bronchoalveolar lavage fluid [132]. Following on this discovery, Patel and Webley then used a mouse model of respiratory Chlamydia infection to demonstrate that airway neutrophils produce large amounts of the inflammatory mediators hepoxilin $\mathrm{A}_{3}$ and histamine [133]. However, the propensity of neutrophils to exacerbate inflammatory conditions in asthma is neither restricted to bacterial pathogens nor to the airways. Neutrophils isolated from the peripheral blood of asthmatics were found to have enhanced secretion of CXCL8 in response to the viral surrogate and TLR agonist R848 compared to non-asthmatics [134], which may provide an explanation for why patients with viral respiratory tract infections are more likely to experience treatment failures [135]. While most therapies are directed at treating eosinophil-mediated allergic asthma, options for developing neutrophil-directed asthma treatments have been investigated. The macrolide antibiotic clarithromycin has previously shown promise in suppression of neutrophilic inflammation in patients with refractory asthma as shown by a reduction in sputum CXCL8 concentration and neutrophil presence [136]. While a variety of therapies targeting neutrophilic asthma have proven ineffective, as reviewed recently by Seys et al. [137], an increased understanding of neutrophil dysregulation in diseased airways will hopefully enable much-needed therapeutic breakthroughs.

\subsection{Chronic Obstructive Pulmonary Disease (COPD)}

COPD has emerged as one of the most common causes of morbidity and mortality worldwide. Caused mostly by exposure to environmental factors such as tobacco smoke and pollution [138], COPD also depends on underlying genetic predispositions [139]. As with CF, lung disease in COPD is characterized by a heavy neutrophil component [140], with extracellular NE being associated with severity of disease and exacerbations [141-143]. In addition, it was observed by Chrysanthopoulou that exposure to cigarette smoke induces NET formation which contributes to lung fibrosis [144]. Recently, Genschmer et al. highlighted a new mechanism of NE-induced lung damage, showing that $\mathrm{NE}$ in the airways of COPD patients is localized on the surface of exosomes [145] forming an active NE pool resistant to inhibition by $\alpha 1$-antitrypsin. While this study provides strong evidence for the damage phenotype, Garratt et al. showed that NE inhibition by $\alpha 1$-antitrypsin mitigated epithelial repair [146], suggesting a potential physiological role for NE-associated exosomes in mediating epithelial repair. Indeed, NE acts on epithelial surfaces by triggering pro-reparative epidermal growth factor signaling $[147,148]$.

Exposure to tobacco smoke and pollution has been well studied, but a new trend showing intriguing effects on innate immunity is the use of electronic cigarettes. Exposure to vaporized nicotine and e-liquid base from electronic cigarettes was found several years ago to impair bacterial killing by neutrophils [149], as with a more recent finding using neutrophils exposed to total particulate matter from conventional cigarette smoke [150]. While neutrophil bactericidal capacity was found to be impaired, the activation and production of inflammatory markers and mediators were augmented upon exposure to e-cigarette vapor extract, as demonstrated by Higham et al. Neutrophils showed increased expression of surface CD11b and CD66b and secreted more MMP-9 and CXCL8, while NE activity was found to be increased in culture conditions [151]. In addition, blood neutrophils isolated from e-cigarette users showed elevated susceptibility to the induction of NETosis, which was supported by an increased presence of NET-related proteins in the sputum of these subjects compared to non-smokers [152]. These findings of neutrophil activation in response to e-cigarette components closely mirror what is observed in COPD due to smoke and air pollution exposure and provide solid evidence for similarly detrimental impact on lung health due to induction of neutrophilic inflammation.

\subsection{Transfusion-Related Acute Lung Injury (TRALI)}

Transfusion-related acute lung injury (TRALI) is one of the leading causes of transfusion-induced morbidity and mortality. It manifests within 6 hours following transfusion with fever and hypoxemia, followed by bilateral pulmonary edema $[153,154]$. Observed since the 1950 s but only defined as a 
distinct syndrome in 1983 [155], TRALI is thought to be triggered by two factors-known as the "two-hit theory" [156] - implicating the status of the transfused material and the vulnerability of the recipient. Studies by Toy et al. [157] and Popovsky [158] identified several risk factors associated with TRALI, including mechanical ventilation, sepsis and female-derived blood. The role of neutrophils in TRALI is highlighted by their increased recruitment in the pulmonary capillary bed and into the alveolar space [159], the presence of neutrophil-derived proteases, and the production of reactive oxygen species, which have been described as mediators of lung injury [160-162]. Although the precise temporal sequence of the events of the "two-hit theory" remains unclear, it is thought that neutrophils primed by the patient's underlying condition adhere to the pulmonary endothelium and that platelets play a major role in further activating them [163]. Several components have been identified as possible mediators of the second hit. Antibodies against HLA class I or class II, and human neutrophil antigens in donor and recipient blood have been implicated in neutrophil activation and subsequent capillary leakage into the alveoli, resulting in pulmonary edema [164-167]. Alterations following increased storage time of red blood cells prior to transfusion have been investigated as a possible cause of neutrophil activation in pre-clinical models [168] and in clinical studies $[169,170]$. Differences detected in pre-clinical models did not occur in patients, suggesting that longer storage-within the clinically allowed time-is not sufficient to induce the same type of neutrophil activation in humans as in animal models. Bioactive lipids, formed during storage, have also been investigated for their ability to promote TRALI, yielding contradicting results $[168,171]$, further suggesting a role for factors related to donor specificity [172-174]. The complement system [175], gut microbiota [176], and other soluble factors, such as osteopontin [177], have also been suggested to play a role in neutrophil accumulation and capillary leakage leading to TRALI. Of note, certain clinical subsets of TRALI do not implicate neutrophils as the key pathogenic cell subset as illustrated by the occurrence of TRALI in neutropenic patients $[178,179]$ and in neutrophil-depleted animal models [180]. In conclusion, the mechanisms underlying the recruitment, activation, and pathological role of neutrophils need to be better understood.

\section{Conclusions}

Recent advances in understanding neutrophil biology in health and disease emphasize the plasticity of these cells. Despite comprising the largest proportion of circulating leukocytes, studying the molecular mechanisms of neutrophil function is still a relatively new endeavor in the field of immunology. The identification and clearance of microbes by neutrophils is now well understood, but this represents only a small sample of their functional capabilities. These functional capabilities depend on an array of signaling and effector proteins (Table 1).

There is now a growing interest in the contribution of neutrophils in chronic disease, especially those relating to the lungs. First, while neutrophilic inflammation has long been known to have a role in CF and COPD, new mechanisms are uncovered by which they may contribute to lung damage. Second, new studies of asthma are shedding light on pathological mechanisms that are driven by a neutrophilic response despite typically being thought of as a type 2-dominated eosinophilic airway disease. Third, considering the monogenic disease CF where the focus has historically been on the mutated CF Transmembrane conductance Regulator ion channel (expressed primarily in epithelial cells), recent studies have indicated that early and sustained neutrophil recruitment to the airways and activation in the mucostatic environment of the CF lung is a major factor in the initiation and progression of lung disease $[18,181,182]$. With our improved understanding of neutrophil contribution to chronic diseases and new data demonstrating metabolic and transcriptional adaptions of neutrophils in these circumstances, neutrophil-directed therapies may soon become an option for the innovative treatment of diseases characterized by chronic neutrophilic inflammation, such as CF and COPD, or acute inflammation such as TRALI.

Author Contributions: V.D.G. and C.M. wrote the manuscript; V.D.G. produced the illustrations; M.A.M. and R.T. edited and approved the final version. All authors have read and agreed to the published version of the manuscript. 
Funding: This research received no external funding.

Conflicts of Interest: The authors declare no conflict of interest.

\section{Abbreviations}

$\begin{array}{ll}\text { ARDS } & \text { acute respiratory distress syndrome } \\ \text { Arg1 } & \text { arginase-1 } \\ \text { CF } & \text { cystic fibrosis } \\ \text { COPD } & \text { chronic obstructive pulmonary disease } \\ \text { GRIM } & \text { granule releasing, immunomodulatory, and metabolically active } \\ \text { IAV } & \text { influenza A virus } \\ \text { iNOS } & \text { inducible nitric oxide synthase } \\ \text { LAIR-1 } & \text { leukocyte-associated Ig-like receptor 1 } \\ \text { MAVS } & \text { mitochondrial antiviral-signaling protein } \\ \text { MMP-9 } & \text { matrix metalloproteinase-9 } \\ \text { MPO } & \text { myeloperoxidase } \\ \text { mTOR } & \text { mechanistic target of rapamycin } \\ \text { MyD88 } & \text { myeloid differentiation primary response } 88 \\ \text { NE } & \text { neutrophil elastase } \\ \text { NETs } & \text { neutrophil extracellular traps; } \\ \text { NO } & \text { nitric oxide } \\ \text { NLRP3 } & \text { NOD-, LRR- and pyrin domain-containing protein } 3 \\ \text { NOX } & \text { nicotinamide adenine dinucleotide phosphate oxidase } \\ \text { OxCAMKII } & \text { oxidized calmodulin-dependent protein kinase II } \\ \text { PAD4 } & \text { peptidyl arginine deiminase } 4 \\ \text { ROS } & \text { reactive oxygen species } \\ \text { RSV } & \text { respiratory syncytial virus } \\ \text { TLR } & \text { Toll-like receptor } \\ \text { TRALI } & \text { transfusion-related acute lung injury } \\ \text { TRIF } & \text { TIR-domain-containing adapter-inducing interferon- } \beta \\ & \end{array}$

\section{References}

1. Segal, A.W. How neutrophils kill microbes. Annu. Rev. Immunol. 2005, 23, 197-223. [CrossRef]

2. Gazendam, R.P.; van de Geer, A.; Roos, D.; van den Berg, T.K.; Kuijpers, T.W. How neutrophils kill fungi. Immunol. Rev. 2016, 273, 299-311. [CrossRef] [PubMed]

3. Jenne, C.N.; Wong, C.H.; Zemp, F.J.; McDonald, B.; Rahman, M.M.; Forsyth, P.A.; McFadden, G.; Kubes, P. Neutrophils recruited to sites of infection protect from virus challenge by releasing neutrophil extracellular traps. Cell Host Microbe 2013, 13, 169-180. [CrossRef] [PubMed]

4. Ingersoll, S.A.; Laval, J.; Forrest, O.A.; Preininger, M.; Brown, M.R.; Arafat, D.; Gibson, G.; Tangpricha, V.; Tirouvanziam, R. Mature cystic fibrosis airway neutrophils suppress T cell function: Evidence for a role of arginase 1 but not programmed death-ligand 1. J. Immunol. 2015, 194, 5520-5528. [CrossRef] [PubMed]

5. Sippel, T.R.; White, J.; Nag, K.; Tsvankin, V.; Klaassen, M.; Kleinschmidt-DeMasters, B.K.; Waziri, A. Neutrophil degranulation and immunosuppression in patients with GBM: Restoration of cellular immune function by targeting arginase I. Clin. Cancer Res. 2011, 17, 6992-7002. [CrossRef]

6. Domon, H.; Nagai, K.; Maekawa, T.; Oda, M.; Yonezawa, D.; Takeda, W.; Hiyoshi, T.; Tamura, H.; Yamaguchi, M.; Kawabata, S.; et al. Neutrophil elastase subverts the immune response by cleaving Toll-like receptors and cytokines in pneumococcal pneumonia. Front. Immunol. 2018, 9, 732. [CrossRef]

7. Doring, G.; Frank, F.; Boudier, C.; Herbert, S.; Fleischer, B.; Bellon, G. Cleavage of lymphocyte surface antigens CD2, CD4, and CD8 by polymorphonuclear leukocyte elastase and cathepsin $\mathrm{G}$ in patients with cystic fibrosis. J. Immunol. 1995, 154, 4842-4850.

8. Folds, J.D.; Prince, H.; Spitznagel, J.K. Limited cleavage of human immunoglobulins by elastase of human neutrophil polymorphonuclear granulocytes. Possible modulator of immune complex disease. Lab. Investig. $1978,39,313-321$. 
9. Silvestre-Roig, C.; Fridlender, Z.G.; Glogauer, M.; Scapini, P. Neutrophil diversity in health and disease. Trends Immunol. 2019, 40, 565-583. [CrossRef]

10. Geng, S.; Zhang, Y.; Lee, C.; Li, L. Novel reprogramming of neutrophils modulates inflammation resolution during atherosclerosis. Sci. Adv. 2019, 5, eaav2309. [CrossRef]

11. Margaroli, C.; Tirouvanziam, R. Neutrophil plasticity enables the development of pathological microenvironments: Implications for cystic fibrosis airway disease. Mol. Cell Pediatr. 2016, 3, 38. [CrossRef] [PubMed]

12. Laval, J.; Ralhan, A.; Hartl, D. Neutrophils in cystic fibrosis. Biol. Chem. 2016, 397, 485-496. [CrossRef] [PubMed]

13. Hogg, J.C.; Doerschuk, C.M.; Wiggs, B.; Minshall, D. Neutrophil retention during a single transit through the pulmonary circulation. J. Appl. Physiol. 1992, 73, 1683-1685. [CrossRef] [PubMed]

14. Sibille, Y.; Reynolds, H.Y. Macrophages and polymorphonuclear neutrophils in lung defense and injury. Am. Rev. Respir. Dis. 1990, 141, 471-501. [CrossRef]

15. GBD 2015 Chronic Respiratory Disease Collaborators. Global, regional, and national deaths, prevalence, disability-adjusted life years, and years lived with disability for chronic obstructive pulmonary disease and asthma, 1990-2015: A systematic analysis for the Global Burden of Disease Study 2015. Lancet Respir. Med. 2017, 5, 691-706. [CrossRef]

16. Sapey, E.; Patel, J.M.; Greenwood, H.L.; Walton, G.M.; Hazeldine, J.; Sadhra, C.; Parekh, D.; Dancer, R.C.A.; Nightingale, P.; Lord, J.M.; et al. Pulmonary infections in the elderly lead to impaired neutrophil targeting, which is improved by simvastatin. Am. J. Respir. Crit. Care Med. 2017, 196, 1325-1336. [CrossRef]

17. Garratt, L.W.; Sutanto, E.N.; Ling, K.M.; Looi, K.; Iosifidis, T.; Martinovich, K.M.; Shaw, N.C.; Kicic-Starcevich, E.; Knight, D.A.; Ranganathan, S.; et al. Matrix metalloproteinase activation by free neutrophil elastase contributes to bronchiectasis progression in early cystic fibrosis. Eur. Respir. J. 2015, 46, 384-394. [CrossRef]

18. Sly, P.D.; Gangell, C.L.; Chen, L.; Ware, R.S.; Ranganathan, S.; Mott, L.S.; Murray, C.P.; Stick, S.M.; Investigators, A.C. Risk factors for bronchiectasis in children with cystic fibrosis. N. Engl. J. Med. 2013, 368, 1963-1970. [CrossRef]

19. Mall, M.A.; Hartl, D. CFTR: Cystic fibrosis and beyond. Eur. Respir. J. 2014, 44, 1042-1054. [CrossRef]

20. Zhu, B.; Zhang, R.; Li, C.; Jiang, L.; Xiang, M.; Ye, Z.; Kita, H.; Melnick, A.M.; Dent, A.L.; Sun, J. BCL6 modulates tissue neutrophil survival and exacerbates pulmonary inflammation following influenza virus infection. Proc. Natl. Acad. Sci. USA 2019, 116, 11888-11893. [CrossRef]

21. Casulli, J.; Fife, M.E.; Houston, S.A.; Rossi, S.; Dow, J.; Williamson, E.D.; Clark, G.C.; Hussell, T.; D’Elia, R.V.; Travis, M.A. CD200R deletion promotes a neutrophil niche for Francisella tularensis and increases infectious burden and mortality. Nat. Commun. 2019, 10, 2121. [CrossRef] [PubMed]

22. Kulkarni, U.; Zemans, R.L.; Smith, C.A.; Wood, S.C.; Deng, J.C.; Goldstein, D.R. Excessive neutrophil levels in the lung underlie the age-associated increase in influenza mortality. Mucosal Immunol. 2019, 12, 545-554. [CrossRef] [PubMed]

23. Devi, S.; Wang, Y.; Chew, W.K.; Lima, R.; A-González, N.; Mattar, C.N.; Chong, S.Z.; Schlitzer, A.; Bakocevic, N.; Chew, S.; et al. Neutrophil mobilization via plerixafor-mediated CXCR4 inhibition arises from lung demargination and blockade of neutrophil homing to the bone marrow. J. Exp. Med. 2013, 210, 2321-2336. [CrossRef] [PubMed]

24. Griffiths, J.S.; Thompson, A.; Stott, M.; Benny, A.; Lewis, N.A.; Taylor, P.R.; Forton, J.; Herrick, S.; Orr, S.J.; McGreal, E.P. Differential susceptibility of Dectin-1 isoforms to functional inactivation by neutrophil and fungal proteases. FASEB J. 2018, 32, 3385-3397. [CrossRef]

25. Adams, L.; Franco, M.C.; Estevez, A.G. Reactive nitrogen species in cellular signaling. Exp. Biol. Med. 2015, 240, 711-717. [CrossRef] [PubMed]

26. Verbrugge, A.; de Ruiter, T.; Geest, C.; Coffer, P.J.; Meyaard, L. Differential expression of leukocyte-associated Ig-like receptor-1 during neutrophil differentiation and activation. J. Leukoc. Biol. 2006, 79, 828-836. [CrossRef] [PubMed]

27. Kumawat, K.; Geerdink, R.J.; Hennus, M.P.; Roda, M.A.; van Ark, I.; Leusink-Muis, T.; Folkerts, G.; van Oort-Jansen, A.; Mazharian, A.; Watson, S.P.; et al. LAIR-1 limits neutrophilic airway inflammation. Front. Immunol. 2019, 10, 842. [CrossRef] 
28. Van Dalen, C.J.; Whitehouse, M.W.; Winterbourn, C.C.; Kettle, A.J. Thiocyanate and chloride as competing substrates for myeloperoxidase. Biochem. J. 1997, 327, 487-492. [CrossRef]

29. Chakrabarti, S.; Patel, K.D. Matrix metalloproteinase-2 (MMP-2) and MMP-9 in pulmonary pathology. Exp. Lung Res. 2005, 31, 599-621. [CrossRef]

30. Hilliard, T.N.; Regamey, N.; Shute, J.K.; Nicholson, A.G.; Alton, E.W.; Bush, A.; Davies, J.C. Airway remodelling in children with cystic fibrosis. Thorax 2007, 62, 1074-1080. [CrossRef]

31. Andrewes, F.W. The Croonian lectures on the behaviour of the leucocytes in infection and immunity. Lancet 1910, 175, 1737-1743. [CrossRef]

32. Cartwright, G.E.; Athens, J.W.; Wintrobe, M.M. The kinetics of granulopoiesis in normal man. Blood 1964, 24, 780-803. [CrossRef] [PubMed]

33. Doerschuk, C.M.; Allard, M.F.; Martin, B.A.; MacKenzie, A.; Autor, A.P.; Hogg, J.C. Marginated pool of neutrophils in rabbit lungs. J. Appl. Physiol. (1985) 1987, 63, 1806-1815. [CrossRef] [PubMed]

34. Martin, B.A.; Wright, J.L.; Thommasen, H.; Hogg, J.C. Effect of pulmonary blood flow on the exchange between the circulating and marginating pool of polymorphonuclear leukocytes in dog lungs. J. Clin. Investig. 1982, 69, 1277-1285. [CrossRef] [PubMed]

35. Schwab, A.J.; Salamand, A.; Merhi, Y.; Simard, A.; Dupuis, J. Kinetic analysis of pulmonary neutrophil retention in vivo using the multiple-indicator-dilution technique. J. Appl. Physiol. (1985) 2003, 95, $279-291$. [CrossRef] [PubMed]

36. Lien, D.C.; Wagner, W.W., Jr.; Capen, R.L.; Haslett, C.; Hanson, W.L.; Hofmeister, S.E.; Henson, P.M.; Worthen, G.S. Physiological neutrophil sequestration in the lung: Visual evidence for localization in capillaries. J. Appl. Physiol. (1985) 1987, 62, 1236-1243. [CrossRef] [PubMed]

37. Wiggs, B.R.; English, D.; Quinlan, W.M.; Doyle, N.A.; Hogg, J.C.; Doerschuk, C.M. Contributions of capillary pathway size and neutrophil deformability to neutrophil transit through rabbit lungs. J. Appl. Physiol. (1985) 1994, 77, 463-470. [CrossRef]

38. Downey, G.P.; Worthen, G.S. Neutrophil retention in model capillaries: Deformability, geometry, and hydrodynamic forces. J. Appl. Physiol. (1985) 1988, 65, 1861-1871. [CrossRef]

39. Downey, G.P.; Doherty, D.E.; Schwab, B., 3rd; Elson, E.L.; Henson, P.M.; Worthen, G.S. Retention of leukocytes in capillaries: Role of cell size and deformability. J. Appl. Physiol. (1985) 1990, 69, 1767-1778. [CrossRef]

40. Dimasi, D.; Sun, W.Y.; Bonder, C.S. Neutrophil interactions with the vascular endothelium. Int. Immunopharmacol. 2013, 17, 1167-1175. [CrossRef]

41. Permutt, S.; Bromberger-Barnea, B.; Bane, H.N. Alveolar pressure, pulmonary venous pressure, and the vascular waterfall. Med. Thorac. 1962, 19, 239-260. [CrossRef] [PubMed]

42. Permutt, S.; Riley, R.L. Hemodynamics of collapsible vessels with tone: The vascular waterfall. J. Appl. Physiol. 1963, 18, 924-932. [CrossRef] [PubMed]

43. Yoder, M.C.; Checkley, L.L.; Giger, U.; Hanson, W.L.; Kirk, K.R.; Capen, R.L.; Wagner, W.W., Jr. Pulmonary microcirculatory kinetics of neutrophils deficient in leukocyte adhesion-promoting glycoproteins. J. Appl. Physiol. (1985) 1990, 69, 207-213. [CrossRef] [PubMed]

44. Doyle, N.A.; Bhagwan, S.D.; Meek, B.B.; Kutkoski, G.J.; Steeber, D.A.; Tedder, T.F.; Doerschuk, C.M. Neutrophil margination, sequestration, and emigration in the lungs of L-selectin-deficient mice. J. Clin. Investig. 1997, 99, 526-533. [CrossRef]

45. Kuebler, W.M.; Kuhnle, G.E.; Groh, J.; Goetz, A.E. Contribution of selectins to leucocyte sequestration in pulmonary microvessels by intravital microscopy in rabbits. J. Physiol. 1997, 50, 375-386. [CrossRef]

46. Singh, N.R.; Johnson, A.; Peters, A.M.; Babar, J.; Chilvers, E.R.; Summers, C. Acute lung injury results from failure of neutrophil de-priming: A new hypothesis. Eur. J. Clin. Investig. 2012, 42, 1342-1349. [CrossRef]

47. Ekpenyong, A.E.; Toepfner, N.; Fiddler, C.; Herbig, M.; Li, W.; Cojoc, G.; Summers, C.; Guck, J.; Chilvers, E.R. Mechanical deformation induces depolarization of neutrophils. Sci. Adv. 2017, 3, e1602536. [CrossRef]

48. Summers, C.; Singh, N.R.; White, J.F.; Mackenzie, I.M.; Johnston, A.; Solanki, C.; Balan, K.K.; Peters, A.M.; Chilvers, E.R. Pulmonary retention of primed neutrophils: A novel protective host response, which is impaired in the acute respiratory distress syndrome. Thorax 2014, 69, 623-629. [CrossRef]

49. Kim, J.H.; Podstawka, J.; Lou, Y.; Li, L.; Lee, E.K.S.; Divangahi, M.; Petri, B.; Jirik, F.R.; Kelly, M.M.; Yipp, B.G. Aged polymorphonuclear leukocytes cause fibrotic interstitial lung disease in the absence of regulation by B cells. Nat. Immunol. 2018, 19, 192-201. [CrossRef] 
50. Granton, E.; Kim, J.H.; Podstawka, J.; Yipp, B.G. The lung microvasculature is a functional immune niche. Trends Immunol. 2018, 39, 890-899. [CrossRef]

51. Amulic, B.; Cazalet, C.; Hayes, G.L.; Metzler, K.D.; Zychlinsky, A. Neutrophil function: From mechanisms to disease. Annu. Rev. Immunol. 2012, 30, 459-489. [CrossRef]

52. Naumenko, V.; Turk, M.; Jenne, C.N.; Kim, S.J. Neutrophils in viral infection. Cell Tissue Res. 2018, 371, 505-516. [CrossRef] [PubMed]

53. Galani, I.E.; Andreakos, E. Neutrophils in viral infections: Current concepts and caveats. J. Leukoc. Biol. 2015, 98, 557-564. [CrossRef] [PubMed]

54. Diaz-Godinez, C.; Carrero, J.C. The state of art of neutrophil extracellular traps in protozoan and helminthic infections. Biosci. Rep. 2019, 39. [CrossRef]

55. Lei, B.; Minor, D.; Feng, W.; Jerome, M.; Quinn, M.T.; Jutila, M.A.; Liu, M. Tissue tropism in Streptococcal infection: Wild-type M1T1 group A Streptococcus is efficiently cleared by neutrophils using an NADPH oxidase-dependent mechanism in the lung but not in the skin. Infect. Immun. 2019. [CrossRef] [PubMed]

56. Snelgrove, R.J.; Goulding, J.; Didierlaurent, A.M.; Lyonga, D.; Vekaria, S.; Edwards, L.; Gwyer, E.; Sedgwick, J.D.; Barclay, A.N.; Hussell, T. A critical function for CD200 in lung immune homeostasis and the severity of influenza infection. Nat. Immunol. 2008, 9, 1074-1083. [CrossRef] [PubMed]

57. Hoetzenecker, W.; Echtenacher, B.; Guenova, E.; Hoetzenecker, K.; Woelbing, F.; Bruck, J.; Teske, A.; Valtcheva, N.; Fuchs, K.; Kneilling, M.; et al. ROS-induced ATF3 causes susceptibility to secondary infections during sepsis-associated immunosuppression. Nat. Med. 2011, 18, 128-134. [CrossRef] [PubMed]

58. Vlahos, R.; Stambas, J.; Selemidis, S. Suppressing production of reactive oxygen species (ROS) for influenza A virus therapy. Trends Pharmacol. Sci. 2012, 33, 3-8. [CrossRef]

59. Subramaniam, R.; Barnes, P.F.; Fletcher, K.; Boggaram, V.; Hillberry, Z.; Neuenschwander, P.; Shams, H. Protecting against post-influenza bacterial pneumonia by increasing phagocyte recruitment and ROS production. J. Infect. Dis. 2014, 209, 1827-1836. [CrossRef]

60. Khan, Z.; Shen, X.Z.; Bernstein, E.A.; Giani, J.F.; Eriguchi, M.; Zhao, T.V.; Gonzalez-Villalobos, R.A.; Fuchs, S.; Liu, G.Y.; Bernstein, K.E. Angiotensin-converting enzyme enhances the oxidative response and bactericidal activity of neutrophils. Blood 2017, 130, 328-339. [CrossRef]

61. Yang, W.; Tao, Y.; Wu, Y.; Zhao, X.; Ye, W.; Zhao, D.; Fu, L.; Tian, C.; Yang, J.; He, F.; et al. Neutrophils promote the development of reparative macrophages mediated by ROS to orchestrate liver repair. Nat. Commun. 2019, 10, 1076. [CrossRef] [PubMed]

62. Wright, C.D.; Mulsch, A.; Busse, R.; Osswald, H. Generation of nitric oxide by human neutrophils. Biochem. Biophys. Res. Commun. 1989, 160, 813-819. [CrossRef]

63. Ichinose, M.; Sugiura, H.; Yamagata, S.; Koarai, A.; Shirato, K. Increase in reactive nitrogen species production in chronic obstructive pulmonary disease airways. Am. J. Respir. Crit. Care Med. 2000, 162, 701-706. [CrossRef] [PubMed]

64. Wheeler, M.A.; Smith, S.D.; Garcia-Cardena, G.; Nathan, C.F.; Weiss, R.M.; Sessa, W.C. Bacterial infection induces nitric oxide synthase in human neutrophils. J. Clin. Investig. 1997, 99, 110-116. [CrossRef]

65. Palmer, R.M.; Ashton, D.S.; Moncada, S. Vascular endothelial cells synthesize nitric oxide from L-arginine. Nature 1988, 333, 664-666. [CrossRef]

66. Chang, C.I.; Liao, J.C.; Kuo, L. Arginase modulates nitric oxide production in activated macrophages. Am. J. Physiol. 1998, 274, H342-H348. [CrossRef]

67. Rotondo, R.; Barisione, G.; Mastracci, L.; Grossi, F.; Orengo, A.M.; Costa, R.; Truini, M.; Fabbi, M.; Ferrini, S.; Barbieri, O. IL-8 induces exocytosis of arginase 1 by neutrophil polymorphonuclears in nonsmall cell lung cancer. Int. J. Cancer 2009, 125, 887-893. [CrossRef]

68. Kumar, S.; Gupta, E.; Srivastava, V.K.; Kaushik, S.; Saxena, J.; Goyal, L.K.; Mehta, S.; Jyoti, A. Nitrosative stress and cytokines are linked with the severity of sepsis and organ dysfunction. Br. J. Biomed. Sci. 2019, 76, 29-34. [CrossRef]

69. Shelton, J.L.; Wang, L.; Cepinskas, G.; Sandig, M.; Scott, J.A.; North, M.L.; Inculet, R.; Mehta, S. Inducible NO synthase (iNOS) in human neutrophils but not pulmonary microvascular endothelial cells (PMVEC) mediates septic protein leak in vitro. Microvasc. Res. 2007, 74, 23-31. [CrossRef]

70. Singer, M.; Deutschman, C.S.; Seymour, C.W.; Shankar-Hari, M.; Annane, D.; Bauer, M.; Bellomo, R.; Bernard, G.R.; Chiche, J.D.; Coopersmith, C.M.; et al. The third international consensus definitions for sepsis and septic shock (Sepsis-3). JAMA 2016, 315, 801-810. [CrossRef] 
71. Zhang, F.; Liu, A.L.; Gao, S.; Ma, S.; Guo, S.B. Neutrophil dysfunction in sepsis. Chin. Med. J. (Engl.) 2016, 129, 2741-2744. [CrossRef] [PubMed]

72. Brinkmann, V.; Reichard, U.; Goosmann, C.; Fauler, B.; Uhlemann, Y.; Weiss, D.S.; Weinrauch, Y.; Zychlinsky, A. Neutrophil extracellular traps kill bacteria. Science 2004, 303, 1532-1535. [CrossRef] [PubMed]

73. Sorensen, O.E.; Borregaard, N. Neutrophil extracellular traps-The dark side of neutrophils. J. Clin. Investig. 2016, 126, 1612-1620. [CrossRef] [PubMed]

74. Hamam, H.J.; Khan, M.A.; Palaniyar, N. Histone acetylation promotes neutrophil extracellular trap formation. Biomolecules 2019, 9, 32. [CrossRef]

75. Claushuis, T.A.M.; van der Donk, L.E.H.; Luitse, A.L.; van Veen, H.A.; van der Wel, N.N.; van Vught, L.A.; Roelofs, J.; de Boer, O.J.; Lankelma, J.M.; Boon, L.; et al. Role of peptidylarginine deiminase 4 in neutrophil extracellular trap formation and host defense during Klebsiella pneumoniae-induced pneumonia-derived sepsis. J. Immunol. 2018, 201, 1241-1252. [CrossRef]

76. Guiducci, E.; Lemberg, C.; Kung, N.; Schraner, E.; Theocharides, A.P.A.; LeibundGut-Landmann, S. Candida albicans-induced NETosis is independent of peptidylarginine deiminase 4. Front. Immunol. 2018, 9, 1573. [CrossRef]

77. Yipp, B.G.; Petri, B.; Salina, D.; Jenne, C.N.; Scott, B.N.; Zbytnuik, L.D.; Pittman, K.; Asaduzzaman, M.; Wu, K.; Meijndert, H.C.; et al. Infection-induced NETosis is a dynamic process involving neutrophil multitasking in vivo. Nat. Med. 2012, 18, 1386-1393. [CrossRef]

78. Krishnamoorthy, N.; Douda, D.N.; Bruggemann, T.R.; Ricklefs, I.; Duvall, M.G.; Abdulnour, R.E.; Martinod, K.; Tavares, L.; Wang, X.; Cernadas, M.; et al. Neutrophil cytoplasts induce Th17 differentiation and skew inflammation toward neutrophilia in severe asthma. Sci. Immunol. 2018, 3. [CrossRef]

79. Desai, J.; Mulay, S.R.; Nakazawa, D.; Anders, H.J. Matters of life and death. How neutrophils die or survive along NET release and is "NETosis" = necroptosis? Cell Mol. Life Sci. 2016, 73, 2211-2219. [CrossRef]

80. Yousefi, S.; Stojkov, D.; Germic, N.; Simon, D.; Wang, X.; Benarafa, C.; Simon, H.U. Untangling "NETosis" from NETs. Eur. J. Immunol. 2019, 49, 221-227. [CrossRef]

81. Mikacenic, C.; Moore, R.; Dmyterko, V.; West, T.E.; Altemeier, W.A.; Liles, W.C.; Lood, C. Neutrophil extracellular traps (NETs) are increased in the alveolar spaces of patients with ventilator-associated pneumonia. Crit. Care 2018, 22, 358. [CrossRef] [PubMed]

82. Sharma, N.S.; Lal, C.V.; Li, J.D.; Lou, X.Y.; Viera, L.; Abdallah, T.; King, R.W.; Sethi, J.; Kanagarajah, P.; Restrepo-Jaramillo, R.; et al. The neutrophil chemoattractant peptide proline-glycine-proline is associated with acute respiratory distress syndrome. Am. J. Physiol. Lung Cell Mol. Physiol. 2018, 315, L653-L661. [CrossRef] [PubMed]

83. Chandler, J.D.; Margaroli, C.; Horati, H.; Kilgore, M.B.; Veltman, M.; Liu, H.K.; Taurone, A.J.; Peng, L.; Guglani, L.; Uppal, K.; et al. Myeloperoxidase oxidation of methionine associates with early cystic fibrosis lung disease. Eur. Respir. J. 2018, 52. [CrossRef] [PubMed]

84. Dickerhof, N.; Pearson, J.F.; Hoskin, T.S.; Berry, L.J.; Turner, R.; Sly, P.D.; Kettle, A.J.; Arest, C.F. Oxidative stress in early cystic fibrosis lung disease is exacerbated by airway glutathione deficiency. Free Radic. Biol. Med. 2017, 113, 236-243. [CrossRef]

85. Khan, M.A.; Palaniyar, N. Transcriptional firing helps to drive NETosis. Sci. Rep. 2017, 7, 41749. [CrossRef]

86. Pylaeva, E.; Bordbari, S.; Spyra, I.; Decker, A.S.; Haussler, S.; Vybornov, V.; Lang, S.; Jablonska, J. Detrimental effect of type I IFNs during acute lung infection with Pseudomonas aeruginosa is mediated through the stimulation of neutrophil NETosis. Front. Immunol. 2019, 10, 2190. [CrossRef]

87. Galani, I.E.; Triantafyllia, V.; Eleminiadou, E.E.; Koltsida, O.; Stavropoulos, A.; Manioudaki, M.; Thanos, D.; Doyle, S.E.; Kotenko, S.V.; Thanopoulou, K.; et al. Interferon-lambda mediates non-redundant front-line antiviral protection against influenza virus infection without compromising host fitness. Immunity 2017, 46, 875-890 e6. [CrossRef]

88. Lim, K.; Hyun, Y.M.; Lambert-Emo, K.; Capece, T.; Bae, S.; Miller, R.; Topham, D.J.; Kim, M. Neutrophil trails guide influenza-specific CD8(+) T cells in the airways. Science 2015, 349, aaa4352. [CrossRef]

89. Niu, J.; Wu, S.; Chen, M.; Xu, K.; Guo, Q.; Lu, A.; Zhao, L.; Sun, B.; Meng, G. Hyperactivation of the NLRP3 inflammasome protects mice against influenza A virus infection via IL-1beta mediated neutrophil recruitment. Cytokine 2019, 120, 115-124. [CrossRef] 
90. Keeler, S.P.; Agapov, E.V.; Hinojosa, M.E.; Letvin, A.N.; Wu, K.; Holtzman, M.J. Influenza A virus infection causes chronic lung disease linked to sites of active viral RNA remnants. J. Immunol. 2018, 201, 2354-2368. [CrossRef]

91. Kirsebom, F.C.M.; Kausar, F.; Nuriev, R.; Makris, S.; Johansson, C. Neutrophil recruitment and activation are differentially dependent on MyD88/TRIF and MAVS signaling during RSV infection. Mucosal Immunol. 2019. [CrossRef] [PubMed]

92. Russell, C.D.; Unger, S.A.; Walton, M.; Schwarze, J. The human immune response to respiratory syncytial virus infection. Clin. Microbiol. Rev. 2017, 30, 481-502. [CrossRef] [PubMed]

93. Schonrich, G.; Raftery, M.J. Neutrophil extracellular traps go viral. Front. Immunol. 2016, 7, 366. [CrossRef] [PubMed]

94. Branzk, N.; Papayannopoulos, V. Molecular mechanisms regulating NETosis in infection and disease. Semin. Immunopathol. 2013, 35, 513-530. [CrossRef] [PubMed]

95. Muraro, S.P.; De Souza, G.F.; Gallo, S.W.; Da Silva, B.K.; De Oliveira, S.D.; Vinolo, M.A.R.; Saraiva, E.M.; Porto, B.N. Respiratory Syncytial Virus induces the classical ROS-dependent NETosis through PAD-4 and necroptosis pathways activation. Sci. Rep. 2018, 8, 14166. [CrossRef] [PubMed]

96. Saitoh, T.; Komano, J.; Saitoh, Y.; Misawa, T.; Takahama, M.; Kozaki, T.; Uehata, T.; Iwasaki, H.; Omori, H.; Yamaoka, S.; et al. Neutrophil extracellular traps mediate a host defense response to human immunodeficiency virus-1. Cell Host Microbe 2012, 12, 109-116. [CrossRef]

97. Narasaraju, T.; Yang, E.; Samy, R.P.; Ng, H.H.; Poh, W.P.; Liew, A.A.; Phoon, M.C.; van Rooijen, N.; Chow, V.T. Excessive neutrophils and neutrophil extracellular traps contribute to acute lung injury of influenza pneumonitis. Am. J. Pathol. 2011, 179, 199-210. [CrossRef]

98. Zhu, L.; Liu, L.; Zhang, Y.; Pu, L.; Liu, J.; Li, X.; Chen, Z.; Hao, Y.; Wang, B.; Han, J.; et al. High Level of Neutrophil extracellular traps correlates with poor prognosis of severe influenza A infection. J. Infect. Dis. 2018, 217, 428-437. [CrossRef]

99. Toussaint, M.; Jackson, D.J.; Swieboda, D.; Guedan, A.; Tsourouktsoglou, T.D.; Ching, Y.M.; Radermecker, C.; Makrinioti, H.; Aniscenko, J.; Bartlett, N.W.; et al. Host DNA released by NETosis promotes rhinovirus-induced type-2 allergic asthma exacerbation. Nat. Med. 2017, 23, 681-691. [CrossRef]

100. Moran, G.; Uberti, B.; Ortloff, A.; Folch, H. Aspergillus fumigatus-sensitive IgE is associated with bronchial hypersensitivity in a murine model of neutrophilic airway inflammation. J. Mycol. Med. 2018, 28, 128-136. [CrossRef]

101. Alflen, A.; Prufer, S.; Ebner, K.; Reuter, S.; Aranda Lopez, P.; Scharrer, I.; Banno, F.; Stassen, M.; Schild, H.; Jurk, K.; et al. ADAMTS-13 regulates neutrophil recruitment in a mouse model of invasive pulmonary aspergillosis. Sci. Rep. 2017, 7, 7184. [CrossRef]

102. Gazendam, R.P.; van Hamme, J.L.; Tool, A.T.; Hoogenboezem, M.; van den Berg, J.M.; Prins, J.M.; Vitkov, L.; van de Veerdonk, F.L.; van den Berg, T.K.; Roos, D.; et al. Human neutrophils use different mechanisms to kill Aspergillus fumigatus conidia and hyphae: Evidence from phagocyte defects. J. Immunol. 2016, 196, 1272-1283. [CrossRef] [PubMed]

103. Park, S.J.; Burdick, M.D.; Mehrad, B. Neutrophils mediate maturation and efflux of lung dendritic cells in response to Aspergillus fumigatus germ tubes. Infect. Immun. 2012, 80, 1759-1765. [CrossRef]

104. Engel, T.G.P.; Slabbers, L.; de Jong, C.; Melchers, W.J.G.; Hagen, F.; Verweij, P.E.; Merkus, P.; Meis, J.F.; Dutch Cystic Fibrosis Fungal Collection Consortium. Prevalence and diversity of filamentous fungi in the airways of cystic fibrosis patients-A Dutch, multicentre study. J. Cyst. Fibros. 2019, 18, 221-226. [CrossRef] [PubMed]

105. Tirouvanziam, R.; Gernez, Y.; Conrad, C.K.; Moss, R.B.; Schrijver, I.; Dunn, C.E.; Davies, Z.A.; Herzenberg, L.A.; Herzenberg, L.A. Profound functional and signaling changes in viable inflammatory neutrophils homing to cystic fibrosis airways. Proc. Natl. Acad. Sci. USA 2008, 105, 4335-4339. [CrossRef] [PubMed]

106. Taylor, P.R.; Brown, G.D.; Reid, D.M.; Willment, J.A.; Martinez-Pomares, L.; Gordon, S.; Wong, S.Y. The beta-glucan receptor, dectin-1, is predominantly expressed on the surface of cells of the monocyte/macrophage and neutrophil lineages. J. Immunol. 2002, 169, 3876-3882. [CrossRef]

107. Brown, G.D. Dectin-1: A signalling non-TLR pattern-recognition receptor. Nat. Rev. Immunol. 2006, 6, $33-43$. [CrossRef]

108. Meyer, K.C.; Zimmerman, J. Neutrophil mediators, Pseudomonas, and pulmonary dysfunction in cystic fibrosis. J. Lab. Clin. Med. 1993, 121, 654-661. 
109. McKelvey, M.C.; Weldon, S.; McAuley, D.F.; Mall, M.A.; Taggart, C.C. Targeting proteases in cystic fibrosis lung disease: Paradigms, progress, and potential. Am. J. Respir. Crit. Care Med. 2019. [CrossRef]

110. Cowley, A.C.; Thornton, D.J.; Denning, D.W.; Horsley, A. Aspergillosis and the role of mucins in cystic fibrosis. Pediatr. Pulmonol. 2017, 52, 548-555. [CrossRef]

111. Grunwell, J.R.; Giacalone, V.D.; Stephenson, S.; Margaroli, C.; Dobosh, B.S.; Brown, M.R.; Fitzpatrick, A.M.; Tirouvanziam, R. Neutrophil dysfunction in the airways of children with acute respiratory failure due to lower respiratory tract viral and bacterial coinfections. Sci. Rep. 2019, 9, 2874. [CrossRef] [PubMed]

112. Tsai, Y.F.; Hwang, T.L. Neutrophil elastase inhibitors: A patent review and potential applications for inflammatory lung diseases (2010-2014). Expert. Opin Ther. Pat. 2015, 25, 1145-1158. [CrossRef]

113. Hoenderdos, K.; Condliffe, A. The neutrophil in chronic obstructive pulmonary disease. Am. J. Respir. Cell Mol. Biol. 2013, 48, 531-539. [CrossRef] [PubMed]

114. Tsuda, Y.; Takahashi, H.; Kobayashi, M.; Hanafusa, T.; Herndon, D.N.; Suzuki, F. Three different neutrophil subsets exhibited in mice with different susceptibilities to infection by methicillin-resistant Staphylococcus aureus. Immunity 2004, 21, 215-226. [CrossRef] [PubMed]

115. Guglani, L. Changing the paradigm-treating the basic defect in cystic fibrosis. Indian J. Pediatr. 2015, 82, 727-736. [CrossRef] [PubMed]

116. Forrest, O.A.; Ingersoll, S.A.; Preininger, M.K.; Laval, J.; Limoli, D.H.; Brown, M.R.; Lee, F.E.; Bedi, B.; Sadikot, R.T.; Goldberg, J.B.; et al. Frontline Science: Pathological conditioning of human neutrophils recruited to the airway milieu in cystic fibrosis. J. Leukoc. Biol. 2018, 104, 665-675. [CrossRef]

117. Mitchell, T.C. A GRIM fate for human neutrophils in airway disease. J. Leukoc. Biol. 2018, 104, 657-659. [CrossRef]

118. Margaroli, C.; Garratt, L.W.; Horati, H.; Dittrich, A.S.; Rosenow, T.; Montgomery, S.T.; Frey, D.L.; Brown, M.R.; Schultz, C.; Guglani, L.; et al. Elastase exocytosis by airway neutrophils is associated with early lung damage in children with cystic fibrosis. Am. J. Respir. Crit. Care Med. 2019, 199, 873-881. [CrossRef]

119. Gehrig, S.; Duerr, J.; Weitnauer, M.; Wagner, C.J.; Graeber, S.Y.; Schatterny, J.; Hirtz, S.; Belaaouaj, A.; Dalpke, A.H.; Schultz, C.; et al. Lack of neutrophil elastase reduces inflammation, mucus hypersecretion, and emphysema, but not mucus obstruction, in mice with cystic fibrosis-like lung disease. Am. J. Respir. Crit. Care Med. 2014, 189, 1082-1092. [CrossRef]

120. Guerra, M.; Frey, D.; Hagner, M.; Dittrich, S.; Paulsen, M.; Mall, M.A.; Schultz, C. Cathepsin G activity as a new marker for detecting airway inflammation by microscopy and flow cytometry. ACS Cent. Sci. 2019, 5 , 539-548. [CrossRef]

121. Davis, P.B. Cystic fibrosis since 1938. Am. J. Respir. Crit. Care Med. 2006, 173, 475-482. [CrossRef] [PubMed]

122. Makam, M.; Diaz, D.; Laval, J.; Gernez, Y.; Conrad, C.K.; Dunn, C.E.; Davies, Z.A.; Moss, R.B.; Herzenberg, L.A.; Herzenberg, L.A.; et al. Activation of critical, host-induced, metabolic and stress pathways marks neutrophil entry into cystic fibrosis lungs. Proc. Natl. Acad. Sci. USA 2009, 106, 5779-5783. [CrossRef] [PubMed]

123. Laval, J.; Touhami, J.; Herzenberg, L.A.; Conrad, C.; Taylor, N.; Battini, J.L.; Sitbon, M.; Tirouvanziam, R. Metabolic adaptation of neutrophils in cystic fibrosis airways involves distinct shifts in nutrient transporter expression. J. Immunol. 2013, 190, 6043-6050. [CrossRef] [PubMed]

124. Buller, C.L.; Loberg, R.D.; Fan, M.H.; Zhu, Q.; Park, J.L.; Vesely, E.; Inoki, K.; Guan, K.L.; Brosius, F.C., 3rd. A GSK-3/TSC2/mTOR pathway regulates glucose uptake and GLUT1 glucose transporter expression. Am. J. Physiol. Cell Physiol. 2008, 295, C836-C843. [CrossRef]

125. Baker, E.H.; Clark, N.; Brennan, A.L.; Fisher, D.A.; Gyi, K.M.; Hodson, M.E.; Philips, B.J.; Baines, D.L.; Wood, D.M. Hyperglycemia and cystic fibrosis alter respiratory fluid glucose concentrations estimated by breath condensate analysis. J. Appl. Physiol. (1985) 2007, 102, 1969-1975. [CrossRef]

126. Forrest, O.A.; Chopyk, D.M.; Gernez, Y.; Brown, M.R.; Conrad, C.K.; Moss, R.B.; Tangpricha, V.; Peng, L.; Tirouvanziam, R. Resistin is elevated in cystic fibrosis sputum and correlates negatively with lung function. J. Cyst. Fibros. 2019, 18, 64-70. [CrossRef]

127. Park, H.K.; Kwak, M.K.; Kim, H.J.; Ahima, R.S. Linking resistin, inflammation, and cardiometabolic diseases. Korean J. Intern. Med. 2017, 32, 239-247. [CrossRef]

128. Miller, L.; Singbartl, K.; Chroneos, Z.C.; Ruiz-Velasco, V.; Lang, C.H.; Bonavia, A. Resistin directly inhibits bacterial killing in neutrophils. Intensive Care Med. Exp. 2019, 7, 30. [CrossRef]

129. Aleman, F.; Lim, H.F.; Nair, P. Eosinophilic endotype of asthma. Immunol. Allergy Clin. North. Am. 2016, 36, 559-568. [CrossRef] [PubMed] 
130. McGrath, K.W.; Icitovic, N.; Boushey, H.A.; Lazarus, S.C.; Sutherland, E.R.; Chinchilli, V.M.; Fahy, J.V.; Asthma Clinical Research Network of the National Heart, Lung, and Blood Institute. A large subgroup of mild-to-moderate asthma is persistently noneosinophilic. Am. J. Respir. Crit. Care Med. 2012, 185, 612-619. [CrossRef]

131. Ray, A.; Kolls, J.K. Neutrophilic inflammation in asthma and association with disease severity. Trends Immunol. 2017, 38, 942-954. [CrossRef] [PubMed]

132. Patel, K.K.; Vicencio, A.G.; Du, Z.; Tsirilakis, K.; Salva, P.S.; Webley, W.C. Infectious Chlamydia pneumoniae is associated with elevated interleukin-8 and airway neutrophilia in children with refractory asthma. Pediatr. Infect. Dis. J. 2010, 29, 1093-1098. [CrossRef] [PubMed]

133. Patel, K.K.; Webley, W.C. Respiratory Chlamydia infection induce release of hepoxilin a3 and histamine production by airway neutrophils. Front. Immunol. 2018, 9, 2357. [CrossRef] [PubMed]

134. Tang, F.S.; Van Ly, D.; Spann, K.; Reading, P.C.; Burgess, J.K.; Hartl, D.; Baines, K.J.; Oliver, B.G. Differential neutrophil activation in viral infections: Enhanced TLR-7/8-mediated CXCL8 release in asthma. Respirology 2016, 21, 172-179. [CrossRef] [PubMed]

135. Merckx, J.; Ducharme, F.M.; Martineau, C.; Zemek, R.; Gravel, J.; Chalut, D.; Poonai, N.; Quach, C.; Pediatric Emergency Research Canada (PERC) DOORWAY Team. Respiratory viruses and treatment failure in children with asthma exacerbation. Pediatrics 2018, 142. [CrossRef] [PubMed]

136. Simpson, J.L.; Powell, H.; Boyle, M.J.; Scott, R.J.; Gibson, P.G. Clarithromycin targets neutrophilic airway inflammation in refractory asthma. Am. J. Respir. Crit. Care Med. 2008, 177, 148-155. [CrossRef]

137. Seys, S.F.; Lokwani, R.; Simpson, J.L.; Bullens, D.M.A. New insights in neutrophilic asthma. Curr. Opin. Pulm. Med. 2019, 25, 113-120. [CrossRef]

138. Dragonieri, S.; Lacedonia, D.; Scioscia, G.; Palladino, G.P.; Quaranta, V.N.; Carratu, P.; Resta, O.; Foschino Barbaro, M.P.; Carpagnano, G.E. Assessment of induced sputum cellularity in COPD patients belonging to two different classes of air pollution exposure. Arch. Bronconeumol. 2019. [CrossRef]

139. Chang, W.A.; Tsai, M.J.; Jian, S.F.; Sheu, C.C.; Kuo, P.L. Systematic analysis of transcriptomic profiles of COPD airway epithelium using next-generation sequencing and bioinformatics. Int. J. Chron. Obstruct. Pulmon. Dis. 2018, 13, 2387-2398. [CrossRef]

140. Russell, D.W.; Wells, J.M.; Blalock, J.E. Disease phenotyping in chronic obstructive pulmonary disease: The neutrophilic endotype. Curr. Opin. Pulm. Med. 2016, 22, 91-99. [CrossRef]

141. Thulborn, S.J.; Mistry, V.; Brightling, C.E.; Moffitt, K.L.; Ribeiro, D.; Bafadhel, M. Neutrophil elastase as a biomarker for bacterial infection in COPD. Respir. Res. 2019, 20, 170. [CrossRef] [PubMed]

142. Contoli, M.; Baraldo, S.; Conti, V.; Gnesini, G.; Marku, B.; Casolari, P.; Scrigner, P.; Morelli, P.; Saetta, M.; Spanevello, A.; et al. Airway inflammatory profile is correlated with symptoms in stable COPD: A longitudinal proof-of-concept cohort study. Respirology 2019. [CrossRef] [PubMed]

143. Butler, A.; Walton, G.M.; Sapey, E. Neutrophilic inflammation in the pathogenesis of chronic obstructive pulmonary disease. COPD 2018, 15, 392-404. [CrossRef] [PubMed]

144. Chrysanthopoulou, A.; Mitroulis, I.; Apostolidou, E.; Arelaki, S.; Mikroulis, D.; Konstantinidis, T.; Sivridis, E.; Koffa, M.; Giatromanolaki, A.; Boumpas, D.T.; et al. Neutrophil extracellular traps promote differentiation and function of fibroblasts. J. Pathol. 2014, 233, 294-307. [CrossRef]

145. Genschmer, K.R.; Russell, D.W.; Lal, C.; Szul, T.; Bratcher, P.E.; Noerager, B.D.; Abdul Roda, M.; Xu, X.; Rezonzew, G.; Viera, L.; et al. Activated PMN exosomes: Pathogenic entities causing matrix destruction and disease in the lung. Cell 2019, 176, 113-126 e115. [CrossRef]

146. Garratt, L.W.; Sutanto, E.N.; Ling, K.M.; Looi, K.; Iosifidis, T.; Martinovich, K.M.; Shaw, N.C.; Buckley, A.G.; Kicic-Starcevich, E.; Lannigan, F.J.; et al. Alpha-1 antitrypsin mitigates the inhibition of airway epithelial cell repair by neutrophil elastase. Am. J. Respir Cell Mol. Biol. 2016, 54, 341-349. [CrossRef]

147. DiCamillo, S.J.; Carreras, I.; Panchenko, M.V.; Stone, P.J.; Nugent, M.A.; Foster, J.A.; Panchenko, M.P. Elastase-released epidermal growth factor recruits epidermal growth factor receptor and extracellular signal-regulated kinases to down-regulate tropoelastin mRNA in lung fibroblasts. J. Biol. Chem. 2002, 277, 18938-18946. [CrossRef]

148. Cosgrove, S.; Chotirmall, S.H.; Greene, C.M.; McElvaney, N.G. Pulmonary proteases in the cystic fibrosis lung induce interleukin 8 expression from bronchial epithelial cells via a heme/meprin/epidermal growth factor receptor/Toll-like receptor pathway. J. Biol. Chem. 2011, 286, 7692-7704. [CrossRef] 
149. Hwang, J.H.; Lyes, M.; Sladewski, K.; Enany, S.; McEachern, E.; Mathew, D.P.; Das, S.; Moshensky, A.; Bapat, S.; Pride, D.T.; et al. Electronic cigarette inhalation alters innate immunity and airway cytokines while increasing the virulence of colonizing bacteria. J. Mol. Med. (Berl.) 2016, 94, 667-679. [CrossRef]

150. Zhang, Y.; Geng, S.; Prasad, G.L.; Li, L. Suppression of neutrophil antimicrobial functions by total particulate matter from cigarette smoke. Front. Immunol. 2018, 9, 2274. [CrossRef]

151. Higham, A.; Rattray, N.J.; Dewhurst, J.A.; Trivedi, D.K.; Fowler, S.J.; Goodacre, R.; Singh, D. Electronic cigarette exposure triggers neutrophil inflammatory responses. Respir. Res. 2016, 17, 56. [CrossRef] [PubMed]

152. Reidel, B.; Radicioni, G.; Clapp, P.W.; Ford, A.A.; Abdelwahab, S.; Rebuli, M.E.; Haridass, P.; Alexis, N.E.; Jaspers, I.; Kesimer, M. E-Cigarette use causes a unique innate immune response in the lung, involving increased neutrophilic activation and altered mucin secretion. Am. J. Respir. Crit. Care Med. 2018, 197, 492-501. [CrossRef] [PubMed]

153. Muller, J.Y. Nobel prize and the history of blood transfusion. Transfus. Clin. Biol. 2019, 26, 135-143. [CrossRef] [PubMed]

154. Knopfelmacher, A.M. Transfusion-related acute lung injury (TRALI). In Oncologic Critical Care; Nates, J.L., Price, K.J., Eds.; Springer International Publishing: Cham, Switzerland, 2020; pp. 1191-1196. [CrossRef]

155. Popovsky, M.A.; Abel, M.D.; Moore, S.B. Transfusion-related acute lung injury associated with passive transfer of antileukocyte antibodies. Am. Rev. Respir. Dis. 1983, 128, 185-189. [CrossRef]

156. Silliman, C.C.; Voelkel, N.F.; Allard, J.D.; Elzi, D.J.; Tuder, R.M.; Johnson, J.L.; Ambruso, D.R. Plasma and lipids from stored packed red blood cells cause acute lung injury in an animal model. J. Clin. Investig. 1998, 101, 1458-1467. [CrossRef]

157. Toy, P.; Gajic, O.; Bacchetti, P.; Looney, M.R.; Gropper, M.A.; Hubmayr, R.; Lowell, C.A.; Norris, P.J.; Murphy, E.L.; Weiskopf, R.B.; et al. Transfusion-related acute lung injury: Incidence and risk factors. Blood 2012, 119, 1757-1767. [CrossRef]

158. Popovsky, M.A. Transfusion-related acute lung injury: Three decades of progress but miles to go before we sleep. Transfusion 2015, 55, 930-934. [CrossRef]

159. Rebetz, J.; Semple, J.W.; Kapur, R. The pathogenic involvement of neutrophils in acute respiratory distress syndrome and transfusion-related acute lung injury. Transfus. Med. Hemother. 2018, 45, 290-298. [CrossRef]

160. Silliman, C.C.; Curtis, B.R.; Kopko, P.M.; Khan, S.Y.; Kelher, M.R.; Schuller, R.M.; Sannoh, B.; Ambruso, D.R. Donor antibodies to HNA-3a implicated in TRALI reactions prime neutrophils and cause PMN-mediated damage to human pulmonary microvascular endothelial cells in a two-event in vitro model. Blood 2007, 109, 1752-1755. [CrossRef]

161. Ussov, W.Y.; Peters, A.M.; Savill, J.; Pusey, C.D.; Gaskin, G.; Hodgson, H.J.; Goldman, J.M.; Hughes, J.M. Relationship between granulocyte activation, pulmonary granulocyte kinetics and alveolar permeability in extrapulmonary inflammatory disease. Clin. Sci. (Lond.) 1996, 91, 329-335. [CrossRef]

162. Kapur, R.; Kim, M.; Aslam, R.; McVey, M.J.; Tabuchi, A.; Luo, A.; Liu, J.; Li, Y.; Shanmugabhavananthan, S.; Speck, E.R.; et al. T regulatory cells and dendritic cells protect against transfusion-related acute lung injury via IL-10. Blood 2017, 129, 2557-2569. [CrossRef] [PubMed]

163. Looney, M.R.; Nguyen, J.X.; Hu, Y.; Van Ziffle, J.A.; Lowell, C.A.; Matthay, M.A. Platelet depletion and aspirin treatment protect mice in a two-event model of transfusion-related acute lung injury. J. Clin. Investig. 2009, 119, 3450-3461. [CrossRef] [PubMed]

164. Curtis, B.R.; McFarland, J.G. Mechanisms of transfusion-related acute lung injury (TRALI): Anti-leukocyte antibodies. Crit. Care Med. 2006, 34, S118-S123. [CrossRef]

165. Sachs, U.J.; Wasel, W.; Bayat, B.; Bohle, R.M.; Hattar, K.; Berghofer, H.; Reil, A.; Bux, J.; Bein, G.; Santoso, S.; et al. Mechanism of transfusion-related acute lung injury induced by HLA class II antibodies. Blood 2011, 117, 669-677. [CrossRef] [PubMed]

166. Vlaar, A.P.; Hofstra, J.J.; Determann, R.M.; Veelo, D.P.; Paulus, F.; Kulik, W.; Korevaar, J.; de Mol, B.A.; Koopman, M.M.; Porcelijn, L.; et al. The incidence, risk factors, and outcome of transfusion-related acute lung injury in a cohort of cardiac surgery patients: A prospective nested case-control study. Blood 2011, 117, 4218-4225. [CrossRef]

167. Peters, A.L.; Van Stein, D.; Vlaar, A.P. Antibody-mediated transfusion-related acute lung injury; from discovery to prevention. Br. J. Haematol. 2015, 170, 597-614. [CrossRef]

168. Peters, A.L.; van Hezel, M.E.; Juffermans, N.P.; Vlaar, A.P. Pathogenesis of non-antibody mediated transfusion-related acute lung injury from bench to bedside. Blood Rev. 2015, 29, 51-61. [CrossRef] 
169. Alexander, P.E.; Barty, R.; Fei, Y.; Vandvik, P.O.; Pai, M.; Siemieniuk, R.A.; Heddle, N.M.; Blumberg, N.; McLeod, S.L.; Liu, J.; et al. Transfusion of fresher vs older red blood cells in hospitalized patients: A systematic review and meta-analysis. Blood 2016, 127, 400-410. [CrossRef]

170. Peters, A.L.; van Hezel, M.E.; Cortjens, B.; Tuip-de Boer, A.M.; van Bruggen, R.; de Korte, D.; Jonkers, R.E.; Bonta, P.I.; Zeerleder, S.S.; Lutter, R.; et al. Transfusion of 35-day stored RBCs in the presence of endotoxemia does not result in lung injury in humans. Crit. Care Med. 2016, 44, e412-e419. [CrossRef]

171. Maslanka, K.; Smolenska-Sym, G.; Michur, H.; Wrobel, A.; Lachert, E.; Brojer, E. Lysophosphatidylcholines: Bioactive lipids generated during storage of blood components. Arch. Immunol. Ther. Exp. (Warsz.) 2012, 60, 55-60. [CrossRef]

172. Tzounakas, V.L.; Kriebardis, A.G.; Papassideri, I.S.; Antonelou, M.H. Donor-variation effect on red blood cell storage lesion: A close relationship emerges. Proteom. Clin. Appl. 2016, 10, 791-804. [CrossRef] [PubMed]

173. Chasse, M.; McIntyre, L.; English, S.W.; Tinmouth, A.; Knoll, G.; Wolfe, D.; Wilson, K.; Shehata, N.; Forster, A.; van Walraven, C.; et al. Effect of blood donor characteristics on transfusion outcomes: A systematic review and meta-analysis. Transfus. Med. Rev. 2016, 30, 69-80. [CrossRef] [PubMed]

174. Zimring, J.C.; Smith, N.; Stowell, S.R.; Johnsen, J.M.; Bell, L.N.; Francis, R.O.; Hod, E.A.; Hendrickson, J.E.; Roback, J.D.; Spitalnik, S.L. Strain-specific red blood cell storage, metabolism, and eicosanoid generation in a mouse model. Transfusion 2014, 54, 137-148. [CrossRef] [PubMed]

175. Jongerius, I.; Porcelijn, L.; van Beek, A.E.; Semple, J.W.; van der Schoot, C.E.; Vlaar, A.P.J.; Kapur, R. The role of complement in transfusion-related acute lung injury. Transfus. Med. Rev. 2019, 33, 236-242. [CrossRef] [PubMed]

176. Kapur, R.; Kim, M.; Rebetz, J.; Hallstrom, B.; Bjorkman, J.T.; Takabe-French, A.; Kim, N.; Liu, J.; Shanmugabhavananthan, S.; Milosevic, S.; et al. Gastrointestinal microbiota contributes to the development of murine transfusion-related acute lung injury. Blood Adv. 2018, 2, 1651-1663. [CrossRef]

177. Kapur, R.; Kasetty, G.; Rebetz, J.; Egesten, A.; Semple, J.W. Osteopontin mediates murine transfusion-related acute lung injury via stimulation of pulmonary neutrophil accumulation. Blood 2019, 134, 74-84. [CrossRef]

178. Finlayson, J.; Grey, D.; Kavanagh, L.; Witt, C. Transfusion-related acute lung injury in a neutropenic patient. Intern. Med. J. 2011, 41, 638-641. [CrossRef]

179. Danielson, C.; Benjamin, R.J.; Mangano, M.M.; Mills, C.J.; Waxman, D.A. Pulmonary pathology of rapidly fatal transfusion-related acute lung injury reveals minimal evidence of diffuse alveolar damage or alveolar granulocyte infiltration. Transfusion 2008, 48, 2401-2408. [CrossRef]

180. Bayat, B.; Tjahjono, Y.; Sydykov, A.; Werth, S.; Hippenstiel, S.; Weissmann, N.; Sachs, U.J.; Santoso, S. Anti-human neutrophil antigen-3a induced transfusion-related acute lung injury in mice by direct disturbance of lung endothelial cells. Arterioscler. Thromb. Vasc. Biol. 2013, 33, 2538-2548. [CrossRef]

181. Sly, P.D.; Brennan, S.; Gangell, C.; de Klerk, N.; Murray, C.; Mott, L.; Stick, S.M.; Robinson, P.J.; Robertson, C.F.; Ranganathan, S.C.; et al. Lung disease at diagnosis in infants with cystic fibrosis detected by newborn screening. Am. J. Respir. Crit. Care Med. 2009, 180, 146-152. [CrossRef]

182. Balazs, A.; Mall, M.A. Mucus obstruction and inflammation in early cystic fibrosis lung disease: Emerging role of the IL-1 signaling pathway. Pediatr. Pulmonol. 2019, 54 (Suppl. 3), S5-S12. [CrossRef]

(C) 2020 by the authors. Licensee MDPI, Basel, Switzerland. This article is an open access article distributed under the terms and conditions of the Creative Commons Attribution (CC BY) license (http://creativecommons.org/licenses/by/4.0/). 